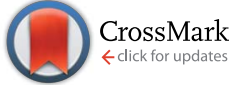

Cite this: RSC Adv., 2017, 7, 17427

Received 12th December 2016 Accepted 15th February 2017

DOI: 10.1039/c6ra28102h

rsc.li/rsc-advances

\section{Laccase-catalyzed green synthesis and cytotoxic activity of novel pyrimidobenzothiazoles and catechol thioetherstt}

\begin{abstract}
H. T. Abdel-Mohsen, ${ }^{a}$ J. Conrad, $^{\text {b }}$ K. Harms, ${ }^{c}$ D. Nohr ${ }^{d}$ and U. Beifuss ${ }^{\star b}$
The laccase-catalyzed reaction between unsubstituted catechol and 2-thioxopyrimidin-4(1H)-ones using aerial $\mathrm{O}_{2}$ as the oxidant delivers novel pyrimidobenzothiazoles with high yields in an aqueous solvent system under mild reaction conditions. With 4-substituted catechols, catechol thioethers are formed exclusively. The synthetic protocols developed provide a sustainable approach for these compound classes. In addition, the cytotoxicity of the products against HepG2 cell line is reported. Most compounds exhibit antiproliferative activities with $I_{50}$ values at the micromolar level. A structureactivity relationship study will facilitate the further development of these compounds as cytotoxic agents.
\end{abstract}

\section{Introduction}

Pyrimidines are the building blocks of pyrimidine nucleosides and thiamine (vitamin B1). Therefore, the pyrimidine skeleton is regarded as an interesting scaffold for the development of molecules with potential applications in medicine. ${ }^{1}$ Over the years, a wide range of pharmaceutical agents with a pyrimidine moiety have been developed. ${ }^{1-3}$ Zidovudine, stavudine and other potent anti-HIV agents are pyrimidines. ${ }^{2,3 a}$ Other important drugs with a pyrimidine ring are the antitumor agents fluorouracil (I), tegafur (II), nimustine (III), monastrol (IV) and pazopanib (V) (Fig. 1). ${ }^{2,3 b, c}$

Recently, the development of more environmentally friendly approaches for the synthesis of pharmaceutical active ingredients has increasingly come into focus of the pharmaceutical chemistry. ${ }^{4}$ Green chemistry is a valuable concept for the development of new, more effective, less toxic and cost efficient methods for the synthesis of bioactive molecules. This can be achieved, for example, by developing highly atom economic transformations, ${ }^{5}$ using nontoxic reagents and catalysts of

${ }^{a}$ Chemistry of Natural and Microbial Products Department, Pharmaceutical Industries Research Division, National Research Centre, Cairo, Egypt

${ }^{b}$ Bioorganische Chemie, Institut für Chemie, Universität Hohenheim, Garbenstr. 30, Stuttgart, D-70599, Germany. E-mail: ubeifuss@uni-hohenheim.de; Fax: +49 711 459 22951; Tel: +4971145922171

${ }^{c}$ Fachbereich Chemie, Universität Marburg, Hans-Meerwein-Str. 4, D-35032 Marburg, Germany

${ }^{d}$ Institut für Biologische Chemie und Ernährungswissenschaft, Universität Hohenheim, Garbenstr. 30, Stuttgart, D-70599, Germany

$\dagger$ This paper is dedicated to Professor Dr Dr hc Wolfgang Haubold on the occasion of his $80^{\text {th }}$ birthday.

\$ Electronic supplementary information (ESI) available: Copies of the ${ }^{1} \mathrm{H}$ NMR and ${ }^{13} \mathrm{C}$ NMR spectra. CCDC 1514742 and 1514743. For ESI and crystallographic data in CIF or other electronic format see DOI: $10.1039 / \mathrm{c} 6 \mathrm{ra} 28102 \mathrm{~h}$ natural origin (e.g. enzymes), the development of one-pot multistep reactions, which reduce the amount of waste formed during reaction and work up as well as the development of environmentally benign reaction conditions., ${ }^{\mathbf{4 6}}$

Hepatocellular carcinoma (HCC) is regarded as one of the leading causes of cancer related mortality in the world. Every year more than half a million new cases with HCC are diagnosed worldwide. Hepatitis $\mathrm{B}$, hepatitis $\mathrm{C}$ viruses and nonalcoholic fatty liver disease are the main risk factors for the development of chronic liver disease and subsequent development of HCC. ${ }^{7 a, b}$ Despite the tremendous progress that has been achieved in cancer therapy over the last decades, the currently available drugs suffer from serious disadvantages, such as lack<smiles>O=c1[nH]cc(F)c(=O)[nH]1</smiles><smiles>O=c1[nH]c(=O)n(C2CCCO2)cc1F</smiles><smiles>Cc1ncc(CNC(=O)N(CCCl)N=O)c(N)n1</smiles>

Fluorouracil

(I)<smiles>CCOC(=O)C1=C(C)NC(=S)NC1c1cccc(O)c1</smiles>
(IV)
Tegafur

(II)
(III)<smiles>Cc1ccc(Nc2nccc(N(C)c3ccc4c(C)n(C)nc4c3)n2)cc1S(N)(=O)=O</smiles>

Fig. 1 Antitumor agents with a pyrimidine moiety. 
of selectivity, toxicity and resistance that limit their use. ${ }^{3 b, 7 c}$ For these reasons, the development of novel anti-tumor agents remains a challenge.

Against this background, the importance of enzymecatalyzed transformations in organic synthesis is steadily growing. ${ }^{8}$ Laccases (benzenediol: $\mathrm{O}_{2}$ oxidoreductase E.C. 1.10.3.2.), which are multicopper oxidases, are among the most attractive enzymes in this respect. ${ }^{9}$ Over the last few years, laccases have proven their ability to catalyze a number of important oxidative transformations in aqueous solvent systems under mild reaction conditions (temperature, $\mathrm{pH}$, pressure) using aerial oxygen as an oxidant. The oxidation of the substrates is linked to the reduction of oxygen to water which is the only byproduct of laccase-catalyzed reactions. Moreover, the application range of laccases can be broadened by employing mediators. Using laccase-mediator systems, the oxidation of substrates with higher oxidation potentials can also be achieved. ${ }^{10}$ Laccases have been successfully used to catalyze the oxidation of a number of functional groups, ${ }^{\mathbf{1 1}}$ the dimerization of phenolic compounds by oxidative coupling ${ }^{12}$ and the oxidation of catechols and hydroquinones to the corresponding highly reactive quinoid systems, followed by reaction with different nucleophiles. ${ }^{\mathbf{1 3 - 1 6}}$ With the latter approach, a range of simple 1,4 -adducts ${ }^{13-15}$ as well as heterocyclic systems ${ }^{\mathbf{1 6}}$ has been made available.

In contrast to the additions of $\mathrm{C}$ and $\mathrm{N}$ nucleophiles, only little is known about laccase-initiated 1,4-additions of $\mathrm{S}$ nucleophiles. ${ }^{\mathbf{1 5 , 1 6 b , \boldsymbol { d }}}$ Recently, we have studied the laccasecatalyzed generation of $o$-quinones and their reaction with different $\mathrm{S}$ nucleophiles for the synthesis of thioethers as well as pyrimidobenzothiazoles. ${ }^{\mathbf{1 5 b}, \mathbf{1 6 \boldsymbol { d }}}$ Ragauskas and coworkers have shown the successful application of laccases for the synthesis of 2,3-ethylenedithio-1,4-quinones. ${ }^{\mathbf{1 6 b}}$ In 2016, Schauer et al. reported on the multiple $\mathrm{C}-\mathrm{S}$ bond formation between $p$-hydroquinones and aromatic thiols using laccase as a catalyst. ${ }^{15 a}$

Here, we report on the laccase-catalyzed reaction between catechols 1 and 2,3-dihydro-2-thioxopyrimidin-4(1H)-ones 2 for the green synthesis of novel biologically active compounds. Depending on the substitution pattern of the catechols $\mathbf{1}$, either pyrimidobenzothiazoles 3, $\mathbf{4}$ or catechol thioethers 5 are formed (Fig. 2). Moreover, the cytotoxic activity of selected reaction products against HepG2 cell line is reported.
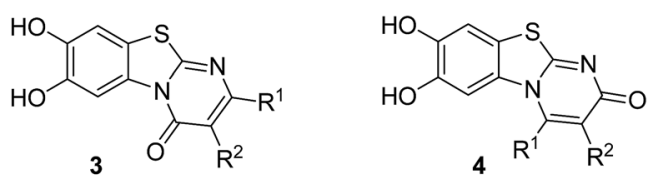<smiles>[R]c1cc(O)c(O)cc1Sc1nc([R])c([R])c(=O)[nH]1</smiles>

Fig. 2 Structures of the regioisomeric pyrimidobenzothiazoles 3, 4 and the catechol thioethers 5 .<smiles>Cc1cc(=O)[nH]c(=S)[nH]1</smiles><smiles>Cc1ccc(O)c(O)c1</smiles><smiles>CCc1ccc(O)c(O)c1</smiles><smiles>CC(C)c1cc(=O)[nH]c(=S)s1</smiles><smiles>CC(C)(C)c1cc(=O)[nH]c(=S)[nH]1</smiles><smiles>O=c1cc(C(F)(F)F)[nH]c(=S)[nH]1</smiles><smiles>Cc1[nH]c(=S)[nH]c(=O)c1C</smiles>

$2 g$
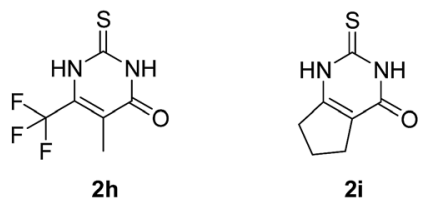

Fig. 3 Substrates for the laccase-catalyzed transformations.

\section{Results and discussion}

Fig. 3 depicts the structures of the catechols 1 and the 2,3dihydro-2-thioxopyrimidin-4(1H)-ones 2 that were chosen as substrates for the enzyme-catalyzed oxidative transformations.

The catechols 1a-c are commercially available, while the 2,3dihydro-2-thioxopyrimidin-4(1H)-ones $\mathbf{2 a - h}$ were synthesized by reaction of different acyclic $\beta$-ketoesters $\mathbf{6 a - h}$ with thiourea (7) under basic conditions in ethanol at $80{ }^{\circ} \mathrm{C}$ (general procedure I). ${ }^{17}$ 2,3,6,7-Tetrahydro-2-thioxo- $1 H$-cyclopenta[ $[d]$ pyrimidin-4(5H)-one (2i) was obtained from cyclic $\beta$-ketoester $\mathbf{6 i}$ as substrate (Scheme 1).

First, the laccase-catalyzed reactions with the unsubstituted catechol (1a) were studied. In an initial experiment, $0.58 \mathrm{mmol}$ (1.16 equiv.) catechol (1a) were reacted with $0.50 \mathrm{mmol}$ (1 equiv.) 2,3-dihydro-6-methyl-2-thioxopyrimidin-4(1H)-one (2a) in the presence of $12 \mathrm{U}$ laccase from Agaricus bisporus $(1.2 \mathrm{U}$ $\left.\mathrm{mg}^{-1}\right)^{18}$ as a catalyst in $20 \mathrm{~mL}$ of a $9: 1$ mixture of phosphate buffer ( $\mathrm{pH} \mathrm{6)}$ and ethanol under air (general procedure II). The reaction proceeded smoothly at room temperature and delivered $97 \%$ of a crude product (purity $>95 \% ;{ }^{1} \mathrm{H}$ NMR) of a $37: 63$ mixture of the two regioisomers 7,8-dihydroxy- $4 \mathrm{H}$-2-methylpyrimido[2,1- $b]$ benzothiazol-4-one (3a) and 7,8-dihydroxy- $2 \mathrm{H}$-4methyl-pyrimido[2,1- $b$ ]benzothiazol-2-one (4a) after $12 \mathrm{~h}$ (Table 1, entry 1). A control experiment was conducted to show that the

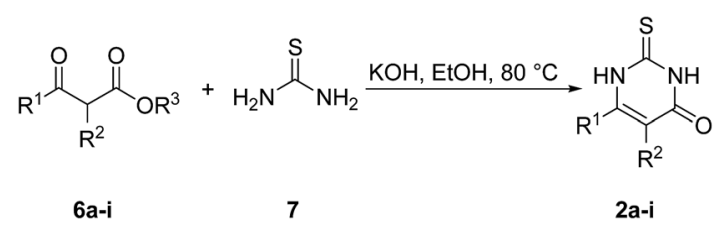

Scheme 1 Synthesis of 2,3-dihydro-2-thioxopyrimidin-4(1H)-ones $2 a-i$. 
Table 1 Laccase-catalyzed reaction between catechol (1a) and 2,3dihydro-2-thioxopyrimidin-4(1H)-ones $2 \mathrm{a}-\mathrm{h}$
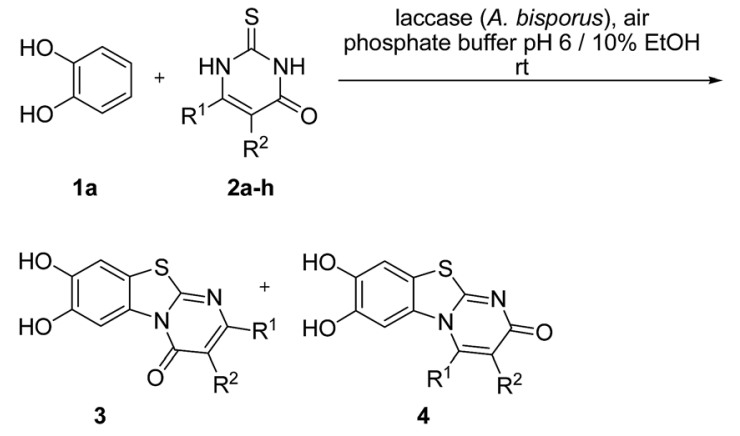

\begin{tabular}{llllllll}
\hline Entry & $\mathbf{2}$ & $\mathrm{R}^{1}$ & $\mathrm{R}^{2}$ & $t(\mathrm{~h})$ & $\mathbf{3}+\mathbf{4}$ & $\mathbf{3}: \mathbf{4}^{d}$ & $\begin{array}{l}\text { Yield of } \\
\mathbf{3}+\mathbf{4}^{e}(\%)\end{array}$ \\
\hline $1^{a}$ & $\mathbf{a}$ & $\mathrm{CH}_{3}$ & $\mathrm{H}$ & 12 & $\mathbf{a}$ & $37: 63$ & 97 \\
$2^{a}$ & $\mathbf{b}$ & $\mathrm{C}_{2} \mathrm{H}_{5}$ & $\mathrm{H}$ & 12 & $\mathbf{b}$ & $54: 46$ & 95 \\
$3^{a}$ & $\mathbf{c}$ & $\mathrm{C}_{3} \mathrm{H}_{7}$ & $\mathrm{H}$ & 18 & $\mathbf{c}$ & $44: 56$ & 94 \\
$4^{a}$ & $\mathbf{d}$ & $\left.\mathrm{CH} \mathrm{CH}_{3}\right)_{2}$ & $\mathrm{H}$ & 13 & $\mathbf{d}$ & $76: 24$ & 95 \\
$5^{a}$ & $\mathbf{e}$ & $\left.\mathrm{C}^{a} \mathrm{CH}_{3}\right)_{3}$ & $\mathrm{H}$ & 16 & $\mathbf{e}$ & $100: 0$ & 97 \\
$6^{a}$ & $\mathbf{f}$ & $\mathrm{CF}_{3}$ & $\mathrm{H}$ & 16 & $\mathbf{f}$ & $100: 0$ & 78 \\
$7^{b}$ & $\mathbf{g}$ & $\mathrm{CH}_{3}$ & $\mathrm{CH}_{3}$ & 28 & $\mathbf{g}$ & $36: 64$ & 89 \\
$8^{b}$ & $\mathbf{h}$ & $\mathrm{CF}_{3}$ & $\mathrm{CH}_{3}$ & 17 & $\mathbf{h}$ & $100: 0$ & $95^{f}$ \\
$9^{c}$ & $\mathbf{a}$ & $\mathrm{CH}_{3}$ & $\mathrm{H}$ & 72 & - & - & $-g^{g}$
\end{tabular}

${ }^{a}$ General procedure II: reactions were carried out using $0.58 \mathrm{mmol}$ catechol (1a), $0.50 \mathrm{mmol}$ 2,3-dihydro-2-thioxopyrimidin-4(1H)-ones 2af, laccase (A. bisporus, $10 \mathrm{mg}, 12 \mathrm{U})$, phosphate buffer pH $6(18 \mathrm{~mL})$ and EtOH $(2 \mathrm{~mL}) .{ }^{b}$ General procedure III: reactions were carried out using $0.29 \mathrm{mmol}$ catechol (1a), $0.25 \mathrm{mmol}$ 2,3-dihydro-2thioxopyrimidin-4(1H)-ones $2 \mathbf{g}, \mathbf{h}$, laccase (A. bisporus, $10 \mathrm{mg}, 12 \mathrm{U}$ ), phosphate buffer pH $6(18 \mathrm{~mL})$ and EtOH $(2 \mathrm{~mL}) .{ }^{c}$ Reaction was carried out using $0.58 \mathrm{mmol} \mathrm{1a}, 0.50 \mathrm{mmol} 2 \mathrm{a}$, phosphate buffer $\mathrm{pH} 6$ $(18 \mathrm{~mL})$ and EtOH $(2 \mathrm{~mL}) .{ }^{d}$ Ratios of regioisomers were determined by ${ }^{1} \mathrm{H}$ NMR of the crude products. ${ }^{e}$ Yields refer to crude products (purity $>95 \%$, as determined by ${ }^{1} \mathrm{H}$ NMR). ${ }^{f}$ Crude product contain traces of unknown impurities. ${ }^{g}$ No reaction.

formation of the two regioisomers 3a and 4a does not proceed in the absence of the laccase (Table 1, entry 9). Subsequently, catechol (1a) was reacted with the other monosubstituted 2,3dihydro-2-thioxopyrimidin-4(1H)-ones $2 \mathbf{b}-\mathbf{f}$ under similar conditions (Table 1 , entries 2-6). With $2 \mathbf{b}-\mathbf{d}$, mixtures of the corresponding regioisomers $\mathbf{3 b} \mathbf{b}-\mathbf{d}$ and $\mathbf{4 b} \mathbf{b}-\mathbf{d}$ were obtained in excellent yields (purity of crude products $>95 \%$; ${ }^{1} \mathrm{H}$ NMR) (Table 1, entries 2-4). When the 6-tert-butyl- and the 6-trifluoromethyl substituted 2,3-dihydro-2-thioxopyrimidin-4(1H)-ones $2 \mathbf{e}, \mathbf{f}$ were used as substrates, the 7,8-dihydroxy- $4 H$-pyrimido[2,1- $b]$ benzothiazol-4-ones $\mathbf{3 e}$ and $\mathbf{3 f}$ were isolated exclusively (Table 1 , entries 5,6$)$. It seems that with increasing space demand of the $\mathrm{R}^{1}$ group in the 2,3-dihydro-2-thioxopyrimidin-4(1H)-ones 2 , the formation of regioisomers 3 is favoured over the formation of 4.

When the disubstituted 2,3-dihydro-2-thioxopyrimidin4(1H)-ones $\mathbf{2 g}$, $\mathbf{h}$ which carry an additional methyl group in 5position were employed as substrates, the reactions were not complete even after $72 \mathrm{~h}$. In addition to the cyclized products $\mathbf{3 g} / \mathbf{4 g}$ and $\mathbf{3 h}$, uncyclized material could be detected by ${ }^{1} \mathrm{H}$ NMR.
Optimization experiments revealed that the reactions can be driven to completion by simply increasing the amount of laccase and solvent by a factor of 2 . When $0.29 \mathrm{mmol}$ catechol (1a) were reacted with $0.25 \mathrm{mmol}$ of the 2,3-dihydro-2-thioxopyrimidin-4(1H)-ones $\mathbf{2 g}$, $\mathbf{h}$ in the presence of $12 \mathrm{U}$ laccase from $A$. bisporus in $20 \mathrm{~mL}$ of a $9: 1$ mixture of phosphate buffer $(\mathrm{pH} 6)$ and ethanol under air (general procedure III) a mixture of regioisomers $3 \mathbf{g}$ and $\mathbf{4 g}$ in $89 \%$ yield (purity of crude product $>95 \% ;{ }^{1} \mathrm{H} \mathrm{NMR}$ ) and the regioisomer $3 \mathbf{h}$ in $95 \%$ yield were isolated (purity of crude product $>95 \% ;{ }^{1} \mathrm{H}$ NMR) (Table 1 , entries 7, 8).

It can be expected that the reactions proceed via the laccasecatalyzed in situ oxidation of catechol (1a) to the highly reactive $o$-quinone (8a) (Scheme 2). The latter one is then attacked at C-4 by the S-atom of the 2,3-dihydro-2-thioxopyrimidin-4(1H)-ones $\mathbf{2 a - h}$ to give the tautomers $9 \mathrm{~A}$ and 10A. The intermolecular 1,4-addition is followed by a second laccase-catalyzed oxidation, namely the oxidation of the intermediates $\mathbf{9 A}$ and $\mathbf{1 0 A}$ to $\mathbf{9 B}$ and $\mathbf{1 0 B}$, respectively. The final intramolecular 1,4-addition proceeds either by nucleophilic attack of $\mathrm{N}-3$ or $\mathrm{N}-1$ and delivers the corresponding regioisomeric cyclization products 3 and $\mathbf{4}$, respectively.

It is interesting to note that the substituent $\mathrm{R}^{1}$ at C- 6 of the 2,3-dihydro-2-thioxopyrimidin-4(1H)-ones $\mathbf{2 a - h}$ exerts a tremendous influence on the ratio of the regioisomeric 7,8-dihydroxy$4 H$-pyrimido[2,1- $b]$ benzothiazol-4-ones 3 and 7,8-dihydroxy- $2 H$ -
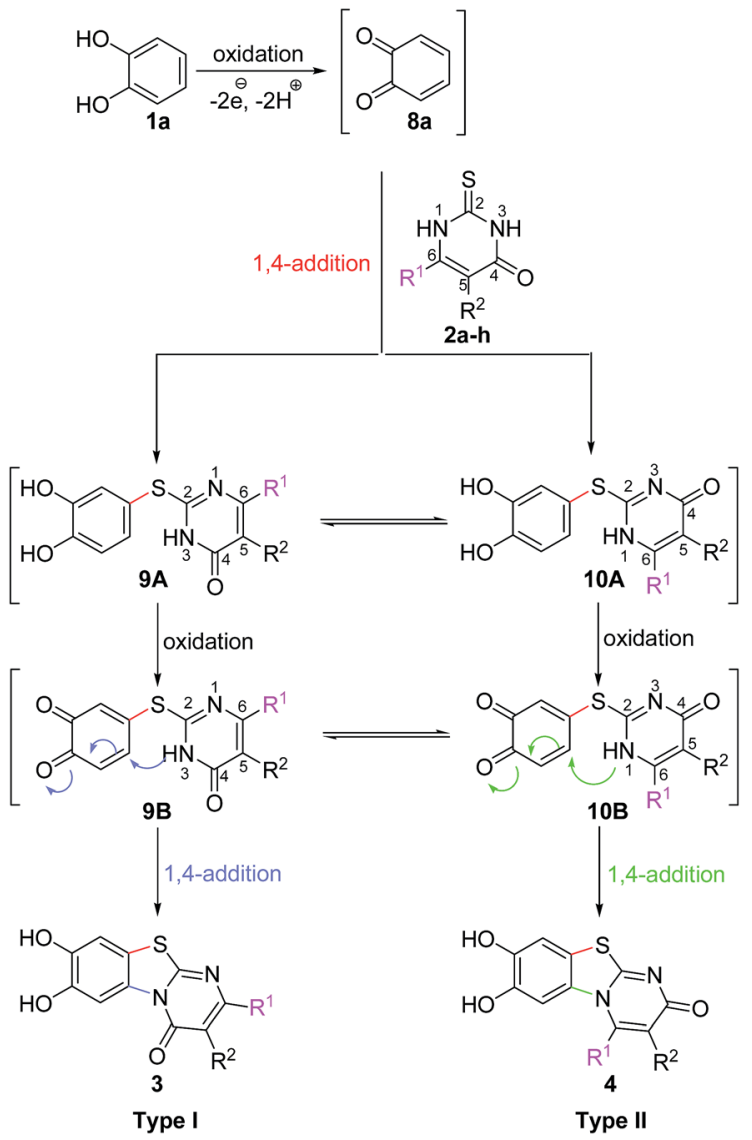

Scheme 2 Mechanistic proposal for the laccase-catalyzed synthesis of pyrimidobenzothiazoles 3, 4 . 
pyrimido[2,1- $b]$ benzothiazol-2-ones 4 . With unbranched alkyl groups at C-6, the formation of 7,8-dihydroxy- $2 \mathrm{H}$-pyrimido[2,1$b$ ]benzothiazol-2-ones 4 is either favoured or roughly equal amounts of the two isomers 3 and $\mathbf{4}$ are observed (Table 1, entries 1-3, 7). With branched alkyl groups (i-propyl- or tertbutyl group) or a trifluoromethyl group at C-6, the 7,8-dihydroxy- $4 H$-pyrimido[2,1- $b]$ benzothiazol-4-ones $\mathbf{3}$ are strongly favoured (Table 1 , entries 4-6,8). These findings are in good agreement with the assumption that the intramolecular 1,4addition via N-1 in 10B to regioisomers 4 (Scheme 2) is hindered by sterically demanding as well as strongly electronegative substituents.

The reactions between $\mathbf{1 a}$ and $\mathbf{2 a - g}$ delivered only either one major product $(\mathbf{3 e}, \mathbf{3 f})$ or two major products, consisting of exclusively mixtures of the regioisomeric products $\mathbf{3 a - d , g}$ and 4a-d,g in remarkably high yields. No other products could be detected by ${ }^{1} \mathrm{H}$ NMR. Only the reaction between $\mathbf{1 a}$ and $2 \mathbf{h}$ delivered in addition to $\mathbf{3 h}$ traces of an additional product of unknown structure (Table 1, entry 8).

Subsequently, the laccase-catalyzed reactions of 4substituted catechols 1b, c with 2,3-dihydro-2-thioxopyrimidin$4(1 H)$-ones $\mathbf{2 a}, \mathbf{c}-\mathbf{e}, \mathbf{g}$ were studied. For this purpose, 4-methylcatechol (1b) and 4-ethylcatechol (1c) were reacted with selected 2,3-dihydro-2-thioxopyrimidin-4(1H)-ones $2 \mathbf{2 a}, \mathbf{c - e}, \mathbf{g}$ under the conditions developed for the reactions of unsubstituted catechol (1a) (general procedure II). In all cases, the corresponding thioethers were formed exclusively with yields ranging between

Table 2 Laccase-catalyzed synthesis of catechol thioethers 5

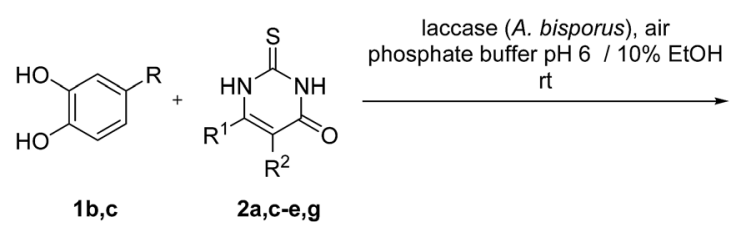<smiles>[R]c1cc(O)c(O)cc1Sc1nc([R])c([R])c(=O)[nH]1</smiles>

\begin{tabular}{|c|c|c|c|c|c|c|c|c|}
\hline Entry $^{a}$ & 1 & $\mathrm{R}$ & 2 & $\mathrm{R}^{1}$ & $\mathrm{R}^{2}$ & Time $(\mathrm{h})$ & 5 & Yield $^{b}(\%)$ \\
\hline 1 & b & $\mathrm{CH}_{3}$ & a & $\mathrm{CH}_{3}$ & $\mathrm{H}$ & 12 & a & 82 \\
\hline 2 & b & $\mathrm{CH}_{3}$ & c & $\mathrm{C}_{3} \mathrm{H}_{7}$ & $\mathrm{H}$ & 13 & b & 88 \\
\hline 3 & b & $\mathrm{CH}_{3}$ & d & $\mathrm{CH}\left(\mathrm{CH}_{3}\right)_{2}$ & $\mathrm{H}$ & 16 & c & 92 \\
\hline 4 & b & $\mathrm{CH}_{3}$ & $\mathbf{e}$ & $\mathrm{C}\left(\mathrm{CH}_{3}\right)_{3}$ & $\mathrm{H}$ & 17 & d & 90 \\
\hline 5 & b & $\mathrm{CH}_{3}$ & $\mathrm{~g}$ & $\mathrm{CH}_{3}$ & $\mathrm{CH}_{3}$ & 20 & e & 86 \\
\hline 6 & c & $\mathrm{C}_{2} \mathrm{H}_{5}$ & a & $\mathrm{CH}_{3}$ & $\mathrm{H}$ & 14 & f & 90 \\
\hline 7 & c & $\mathrm{C}_{2} \mathrm{H}_{5}$ & d & $\mathrm{CH}\left(\mathrm{CH}_{3}\right)_{2}$ & $\mathrm{H}$ & 12 & g & 76 \\
\hline 8 & c & $\mathrm{C}_{2} \mathrm{H}_{5}$ & e & $\mathrm{C}\left(\mathrm{CH}_{3}\right)_{3}$ & $\mathrm{H}$ & 16 & h & 81 \\
\hline 9 & c & $\mathrm{C}_{2} \mathrm{H}_{5}$ & $\mathrm{~g}$ & $\mathrm{CH}_{3}$ & $\mathrm{CH}_{3}$ & 16 & i & 91 \\
\hline
\end{tabular}

${ }^{a}$ General procedure II: reactions were carried out using $0.58 \mathrm{mmol} 4$ substituted catechols $\mathbf{1 b}, \mathbf{c}, 0.50 \mathrm{mmol}$ 2,3-dihydro-2-thioxopyrimidin4(1H)-ones 2a, c-e, g, laccase (A. bisporus, $10 \mathrm{mg}, 12 \mathrm{U}$ ), phosphate buffer $\mathrm{pH} 6(18 \mathrm{~mL})$ and EtOH $(2 \mathrm{~mL}){ }^{b}$ Yields refer to crude products (purity $>95 \%$, as determined by ${ }^{1} \mathrm{H}$ NMR).

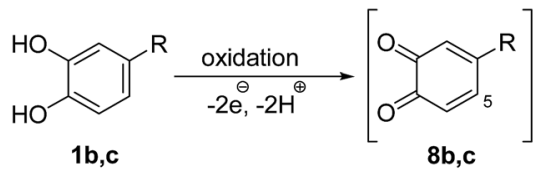<smiles>[R]c1[nH]c(=S)[nH]c(=O)c1[R20]</smiles><smiles>[R]c1cc(O)c(O)cc1Sc1nc([R])c([R])c(=O)[nH]1</smiles>

Scheme 3 Mechanistic proposal for the laccase-catalyzed synthesis of catechol thioethers $5 a-i$.

76 and $92 \%$ (purity of crude products $>95 \% ;{ }^{1} \mathrm{H}$ NMR) (Table 2). Obviously, only the $\mathrm{S}$ atoms of the 2,3-dihydro-2-thioxopyrimidin-4(1H)-ones 2 act as nucleophiles in the intermolecular 1,4-additions. This can be attributed to the higher nucleophilicity of 2-S in comparison to N-1 and N-3 (Scheme 3).

Finally, the laccase-catalyzed reactions between the 4substituted catechols $\mathbf{1 b}$, c and 2,3,6,7-tetrahydro-2-thioxo- $1 \mathrm{H}^{-}$ cyclopenta $[d]$ pyrimidin-4(5H)-one $(2 \mathbf{i})$ were studied (general procedure II) to give the corresponding catechol thioethers $\mathbf{5 j}, \mathbf{k}$ in high yields (Table 3 ).

It can be taken for granted that the reactions start with the laccase-catalyzed oxidation of the 4-substituted catechols $\mathbf{1 b}$, $\mathbf{c}$ to the corresponding $o$-benzoquinones $\mathbf{8 b}$, c. This is followed by intermolecular 1,4-addition of the 2,3-dihydro-2-thioxopyrimidin$4(1 H)$-ones 2 via the $\mathrm{S}$ atom at $\mathrm{C}-5$ to afford the corresponding catechol thioethers $5 \mathbf{a}-\mathbf{i}$ as sole products. Due to the presence of a methyl or an ethyl substituent at C-4 of the catechol, the intramolecular 1,4-addition occurs exclusively at C-5 (Scheme 3).

It should be highlighted that the reactions presented are highly efficient and deliver the products 3,4 and 5 in remarkably

Table 3 Synthesis of dihydroxyphenylthio-6,7-dihydro-3H-cyclopenta[d] pyrimidin-4(5H)-ones $5 \mathrm{j}$, $\mathrm{k}$ by laccase-catalyzed transformations under aerobic conditions

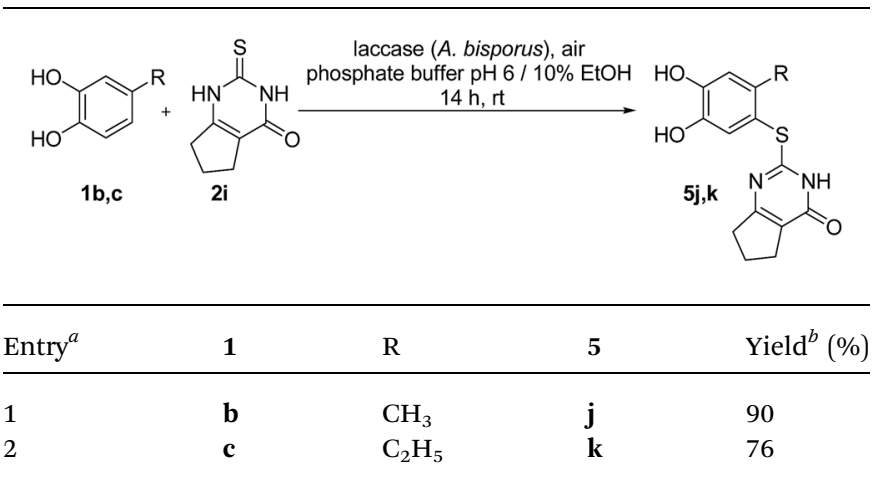

${ }^{a}$ General procedure II: reactions were carried out using $0.58 \mathrm{mmol} 4$ substituted catechols $\mathbf{1 b}$, c, $0.50 \mathrm{mmol}$ 2,3,6,7-tetrahydro-2-thioxo- $1 \mathrm{H}^{-}$ cyclopenta $[d]$ pyrimidin-4(5H)-one (2i), laccase (A. bisporus, $10 \mathrm{mg}, 12$ $\mathrm{U})$, phosphate buffer pH $6(18 \mathrm{~mL})$ and EtOH $(2 \mathrm{~mL}) .{ }^{b}$ Yields refer to crude products (purity $>95 \%$, as determined by ${ }^{1} \mathrm{H}$ NMR). 
high yields and in a highly chemoselective manner. The reactions proceed without the formation of any relevant amounts of byproducts arising from competing reactions, such as (a) the homocoupling of the catechols 1 ; i.e., the reaction of the $o$ quinone intermediates $\mathbf{8}$ with the corresponding parent catechols 1, which is followed by formation of the benzofurans or (b) the formation of disulfides. We assume that this favourable outcome is the result of a combination of several factors. Among them are (a) the high nucleophilicity of the S-nucleophilic substrates 2, (b) the use of a laccase which is particularly suitable for this type of reactions and (c) the careful choice of reaction conditions, such as $\mathrm{pH}$, reaction temperature and substrate concentrations. This view is supported by previous work done in our laboratory. ${ }^{16 k}$ The reactions between catechols and 1,3dicarbonyls prove that the selection of laccase from $A$. bisporus as the catalyst as well as the choice of suitable reaction conditions exert a tremendous impact on product yields.

\section{Structure elucidation}

Structures of all pyrimidobenzothiazole regioisomers 3, 4 as well as catechol thioethers 5 were unambiguously elucidated by mass spectrometry and NMR spectroscopy including 2D NMR for the full assignment of the ${ }^{1} \mathrm{H}$ and ${ }^{13} \mathrm{C}$ chemical shifts. Analysis of the ${ }^{1} \mathrm{H}$ NMR spectrum of the crude products obtained from the reaction between catechol (1a) and 2thioxopyrimidin-4-ones $\mathbf{2 a - h}$ showed the appearance of either a mixture of 2 regioisomers 3 (type I) and $\mathbf{4}$ (type II) or a single regioisomer 3. 2D ROESY as well as super long range gHMBC experiments were carried out to differentiate between the 2 regioisomers. Taking the mixture of $\mathbf{3 a}$ and $\mathbf{4 a}$ as an example, in 4a a strong ROESY correlation between the methyl group at C-4 $\left(\delta_{\mathrm{H}} 2.73 \mathrm{ppm}\right)$ to both the aromatic proton $6-\mathrm{H}\left(\delta_{\mathrm{H}} 7.52 \mathrm{ppm}\right)$ and the aromatic proton $3-\mathrm{H}\left(\delta_{\mathrm{H}} 6.07 \mathrm{ppm}\right)$ confirms the type II regioisomer. However, in 3a only a single ROESY correlation between the methyl group at $\mathrm{C}-2\left(\delta_{\mathrm{H}} 2.26 \mathrm{ppm}\right)$ and the aromatic proton at $3-\mathrm{H}\left(\delta_{\mathrm{H}} 6.17 \mathrm{ppm}\right)$ can be observed (Fig. 4). ${ }^{4} J \mathrm{HMBC}$ correlations (as observed in the super long range gHMBC spectrum) between $6-\mathrm{H}\left(\delta_{\mathrm{H}} 8.44 \mathrm{ppm}\right)$ and $\mathrm{C}-4\left(\delta_{\mathrm{C}} 159.97 \mathrm{ppm}\right)$ along with 9-H ( $\left.\delta_{\mathrm{H}} 7.30 \mathrm{ppm}\right)$ and $\mathrm{C}-10 \mathrm{a}\left(\delta_{\mathrm{C}} 161.71 \mathrm{ppm}\right)$ established a type I regioisomer. Evaluation of the experimental ${ }^{1} \mathrm{H}-{ }^{13} \mathrm{C}$ long-range coupling constants (PIP-HSQMBC), for example in $4 \mathbf{a}$, between $9-\mathrm{H}\left(\delta_{\mathrm{H}} 7.25 \mathrm{ppm}\right)$ to $\mathrm{C}-5 \mathrm{a}\left({ }^{3} J=9.5 \mathrm{~Hz}\right)$

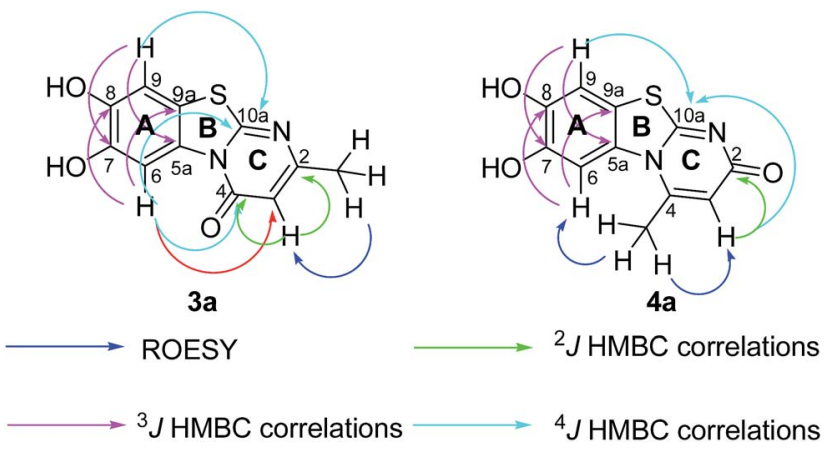

Fig. 4 Important ROESY, ${ }^{2} \mathrm{~J},{ }^{3} \mathrm{~J}$, and ${ }^{4} \mathrm{~J}$ HMBC correlations of $3 a$ and $4 a$.

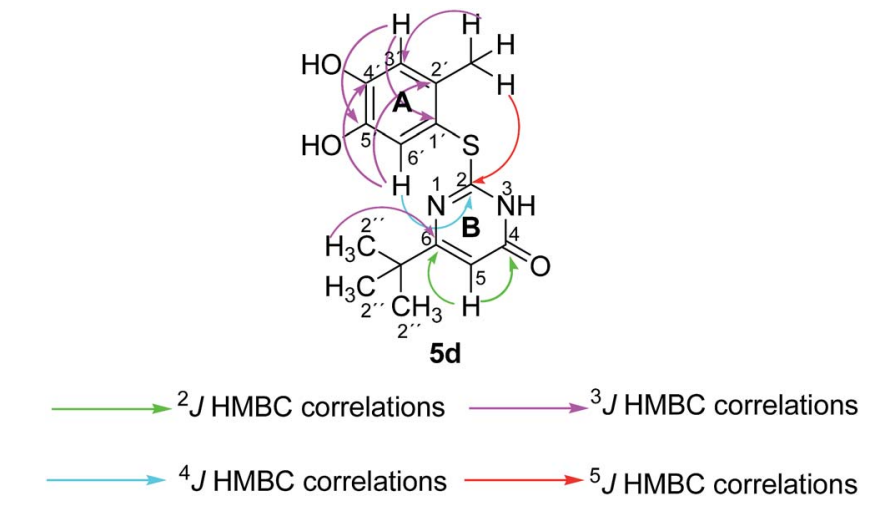

Fig. 5 Important ${ }^{2} \mathrm{~J},{ }^{3} \mathrm{~J},{ }^{4} \mathrm{~J}$ and ${ }^{5} \mathrm{~J} \mathrm{HMBC}$ correlations of $5 \mathrm{~d}$.

and C-7 ( $\left.{ }^{3} J=7.6 \mathrm{~Hz}\right)$ allows the successful assignment of the quaternary carbons $\mathrm{C}-5 \mathrm{a}$ at $\delta_{\mathrm{C}} 128.82 \mathrm{ppm}$ and $\mathrm{C}-7$ at $\delta_{\mathrm{C}}$ $145.25 \mathrm{ppm}$. Similarly, two strong correlations can be seen from H-6 $\left(\delta_{\mathrm{H}} 7.52 \mathrm{ppm}\right)$ to C-9a $\left({ }^{3} J=8.4 \mathrm{~Hz}\right)$ and C-8 $\left({ }^{3} J=6.2 \mathrm{~Hz}\right)$, to be assigned at $\delta_{\mathrm{C}} 112.65 \mathrm{ppm}$ and $\delta_{\mathrm{C}} 144.68 \mathrm{ppm}$, respectively. The quaternary carbons $\mathrm{C}-2, \mathrm{C}-4, \mathrm{C}-10 \mathrm{a}$ of ring $\mathrm{C}$ were assigned by standard gHMBC and super long range gHMBC at $\delta_{\mathrm{C}} 166.32$, 148.31, 164.60 ppm, respectively (Fig. 4).

In the reactions between 4-substituted catechols $\mathbf{1 b}, \mathbf{c}$ and 2thioxopyrimidin-4-ones $\mathbf{2 a}, \mathbf{c}-\mathbf{e}, \mathbf{g}$, $\mathbf{i}$ single products were formed exclusively. The products $5 \mathbf{a}-\mathbf{i}$ consist of the 2 ring systems A and B. Taking $\mathbf{5 d}$ as an example, the complete assignment of ring A was carried out by PIP-HSQMBC ${ }^{1} \mathrm{H}-{ }^{13} \mathrm{C}$ correlations. The difficulty in assigning C-2, C-4, and C-6 was solved by ${ }^{1} \mathrm{H}^{13} \mathrm{C}$ super long gHMBC along with standard gHMBC correlations between $6^{\prime}-\mathrm{H}$ at $\delta_{\mathrm{H}} 7.66 \mathrm{ppm}$ and $\mathrm{C}-2$ at $\delta_{\mathrm{C}} 165.32 \mathrm{ppm}\left({ }^{4} J\right)$ as well as between $2^{\prime}-\mathrm{CH}_{3}$ at $\delta_{\mathrm{H}} 2.42 \mathrm{ppm}$ and $\mathrm{C}-2$ at $\delta_{\mathrm{C}} 165.32 \mathrm{ppm}$ $\left({ }^{5} J\right)$, between $2^{\prime \prime}-\mathrm{H}$ at $\delta_{\mathrm{H}} 1.14$ and C-6 at $\delta_{\mathrm{C}} 176.73 \mathrm{ppm}\left({ }^{3} J\right)$ and finally between $5-\mathrm{H}$ at $\delta_{\mathrm{H}} 6.43 \mathrm{ppm}$ and $\mathrm{C}-4$ at $\delta_{\mathrm{C}} 167.61\left({ }^{2} J\right)$ as well as C-6 at $\delta_{\mathrm{C}} 176.73 \mathrm{ppm}\left({ }^{2} J\right)$ (Fig. 5).

Unequivocal evidence for the structures of $\mathbf{3 f}$ and $5 \mathbf{a}$ was provided by X-ray crystal structure analysis. ${ }^{19}$ The molecular structures of $\mathbf{3 f}$ and 5a are depicted in Fig. 6 and 7.

\section{Greenness of the reactions}

The newly developed methods for the synthesis of pyrimidobenzothiazoles 3, $\mathbf{4}$ and catechol thioethers 5 address many of the principles of green chemistry. ${ }^{6,20}$ The reactions are enzyme-

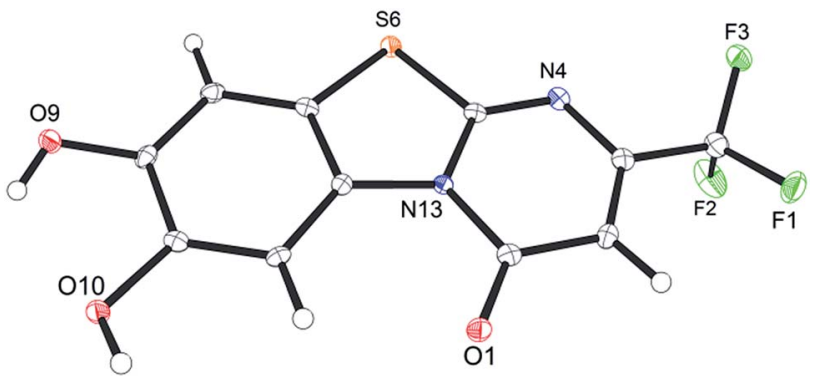

Fig. 6 Molecular structure of 7,8-dihydroxy-4H-2-trifluoromethylpyrimido[2,1-b]benzothiazol-4-one (3f), derived from X-ray crystal structure analysis. 


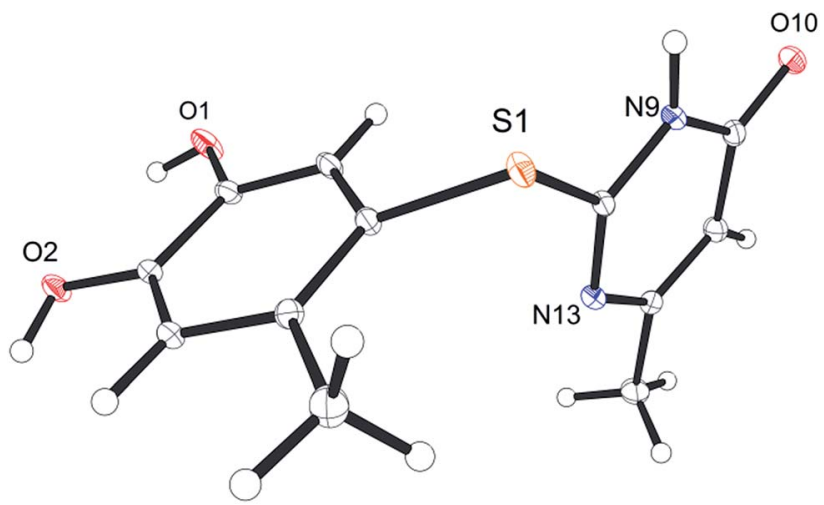

Fig. 7 Molecular structure of 2-(4,5-dihydroxy-2-methylphenylthio)6 -methylpyrimidin-4(3H)-one (5a), derived from X-ray crystal structure analysis.

catalyzed transformations using completely safe and non-toxic aerial oxygen as the sole oxidant. The transformations deliver the pyrimidobenzothiazoles $\mathbf{3}, \mathbf{4}$ and the catechol thioethers $\mathbf{5}$ exclusively and with high yields. The only byproduct formed is water which stems from the reduction of oxygen. The laccasecatalyzed domino reactions presented combine several individual reactions in multistep processes. This allows the reduction of the amount of waste formed during reaction and work up and complies well with the first principle of green chemistry. In addition, environmentally benign reaction conditions have been developed. Taking the preparation of $\mathbf{3 e}$ as a typical example for the synthesis of pyrimidobenzothiazoles 3 , the E-factor ( $\mathrm{kg}$ waste per $\mathrm{kg}$ product) ${ }^{21}$ of the process is $4.57 \mathrm{~kg} \mathrm{~kg}^{-1}$. The atom economy ${ }^{5}$ of this transformation amounts to $94 \%$. The reaction was carried out in a mixture of phosphate buffer (pH 6.0) and 10 vol\% ethanol, which are completely safe and environmentally acceptable solvents. ${ }^{22}$ The method highlights the use of enzymes in catalytic rather than stoichiometric amounts. The turnover number of the laccase in this process is high, for the synthesis of 3e TON amounts to 4656; the turnover frequency of this transformation is good; in the example discussed TOF amounts to 291 $\mathrm{h}^{-1}$. Taking the preparation of $5 \mathbf{j}$ as a representative example for the synthesis of thioethers 5, the E-factor of this process was calculated to be $5.00 \mathrm{~kg} \mathrm{~kg}^{-1}$. The atom economy of this process, calculated as $94 \%$, is also very good. The turnover number and the turnover frequency of the laccase for the synthesis of $5 \mathbf{j}$ are high. They amount to 4320 and $308.57 \mathrm{~h}^{-1}$, respectively.

\section{In vitro cytotoxic activity}

Selected compounds and doxorubicin (positive control) were evaluated for their in vitro cytotoxic activity against HepG2 cancer cell line using SRB assay. ${ }^{23}$ The $\mathrm{IC}_{50}$ values of the tested compounds are summarized in Table 4 . All compounds tested exhibited cytotoxic activities, but all of them were less potent than doxorubicin.

In the catechol thioether series $\mathbf{5 a}-\mathbf{k}$, the substituents on C-5, C-6 and C-2' have a great influence on the cytotoxic activity. In compounds 5a-e, it is assumed that increasing the chain length from methyl in $\mathbf{5 a}\left(\mathrm{IC}_{50}>40 \mu \mathrm{M}\right.$, Table 4 , entry 4) to $n$-propyl in
Table $4 \quad \mathrm{IC}_{50}$ of selected compounds 3, 5 against HepG2 cell line

\begin{tabular}{lll}
\hline Entry & Product & $\mathrm{IC}_{50}{ }^{a, b}(\mu \mathrm{M})$ \\
\hline 1 & $\mathbf{3 d}$ & $23.28 \pm 2.16$ \\
2 & $\mathbf{3 e}$ & $12.70 \pm 0.53$ \\
3 & $\mathbf{3 f}$ & $12.01 \pm 1.46$ \\
4 & $\mathbf{5 a}$ & $>40$ \\
5 & $\mathbf{5 b}$ & $21.25 \pm 0.46$ \\
6 & $\mathbf{5 c}$ & $7.77 \pm 0.30$ \\
7 & $\mathbf{5 d}$ & $14.30 \pm 0.11$ \\
8 & $\mathbf{5 e}$ & $30.57 \pm 1.05$ \\
9 & $\mathbf{5 f}$ & $27.82 \pm 2.36$ \\
10 & $\mathbf{5 g}$ & $2.74 \pm 0.29$ \\
11 & $\mathbf{5 h}$ & $14.92 \pm 1.16$ \\
12 & $\mathbf{5 i}$ & $31.98 \pm 1.43$ \\
13 & $\mathbf{5 j}$ & $40.48 \pm 3.52$ \\
14 & $\mathbf{5 k}$ & $31.34 \pm 3.57$ \\
15 & Doxorubicin & $0.28 \pm 0.04$
\end{tabular}

${ }^{a} \mathrm{IC}_{50}$ are the mean of $2-5$ independent experiments \pm SE. ${ }^{b}$ DMSO alone ( $2 \%$ final concentration) had no effect on the cell viability.

5b $\left(\mathrm{IC}_{50}=21.25 \mu \mathrm{M}\right.$, Table 4 , entry 5$)$ or introduction of a methyl group in the 5-position in $5 \mathbf{e}\left(\mathrm{IC}_{50}=30.57 \mu \mathrm{M}\right.$, Table 4 , entry 8) increases the potency. Moreover, the presence of a branched isopropyl group at C-6 in 5c results in a great increase in potency $\left(\mathrm{IC}_{50}=7.77 \mu \mathrm{M}\right.$, Table 4 , entry 6 ) compared to $5 \mathrm{a}\left(\mathrm{IC}_{50}>40 \mu \mathrm{M}\right.$, Table 4 , entry 4$)$. However, the presence of a bulky tert-butyl group in $\mathbf{5 d}$ results in a decrease of activity $\left(\mathrm{IC}_{50}=14.30 \mu \mathrm{M}\right.$, Table 4 , entry 7$)$ in comparison to $5 \mathrm{c}$. In the $\mathbf{5 f}-\mathbf{i}$ series, where an ethyl group is present at $\mathrm{C}-2^{\prime}$, the introduction of an isopropyl group in $\mathbf{5} \mathbf{g}$ increases the activity $\left(\mathrm{IC}_{50}=\right.$ $2.74 \mu \mathrm{M}$, Table 4 , entry 10) and the presence of a tert-butyl group in $5 \mathrm{~h}$ decreases the potency $\left(\mathrm{IC}_{50}=14.92 \mu \mathrm{M}\right.$, Table 4 , entry 11$)$ in comparison to $\mathbf{5 g}$. Introduction of a methyl group at C-5 of $\mathbf{5 i}$ results in a slight decrease of the cytotoxic activity $\left(\mathrm{IC}_{50}=31.98\right.$ $\mu \mathrm{M}$, Table 4 , entry 12$)$ in comparison to $5 \mathbf{f}\left(\mathrm{IC}_{50}=27.82 \mu \mathrm{M}\right.$, Table 4, entry 9). The presence of a bicyclic system in $5 \mathbf{j}$ and $\mathbf{5 k}$ has no favourable effect on the cytotoxic activity compared to $5 \mathbf{a}$ and $\mathbf{5 f}$. Comparison of the $\mathrm{IC}_{50}$ values of the $\mathbf{5 a - e}, \mathbf{j}$ series with the $\mathbf{5} \mathbf{f}-\mathbf{i}$, $\mathbf{k}$ series reveals that the most potent compounds are $\mathbf{5 c}$ and $5 \mathrm{~g}$ which have an isopropyl group at C-6. The presence of an ethyl group at $\mathbf{C}-2^{\prime}$ of $\mathbf{5 g}$ increases the cytotoxic potency in comparison to $\mathbf{5 c}$. In the pyrimidobenzothiazole derivatives $\mathbf{3 d -}$ f, it was found that replacing the isopropyl group at C-2 of $\mathbf{3 d}$ $\left(\mathrm{IC}_{50}=23.28 \mu \mathrm{M}\right.$, Table 4 , entry 1 ) with a tert-butyl group in $\mathbf{3 e}$ $\left(\mathrm{IC}_{50}=12.70 \mu \mathrm{M}\right.$, Table 4 , entry 2 ) or a trifluoromethyl group in $3 \mathbf{f}\left(\mathrm{IC}_{50}=12.01 \mu \mathrm{M}\right.$, Table 4 , entry 3$)$ results in an increase of the antiproliferative activity. The presented study provides a novel class of compounds, which will be further optimized to increase their potency. The mechanism of their cytotoxic activity is still under study.

\section{Experimental}

\section{Chemistry}

General remarks. All chemicals were purchased from commercial suppliers. Laccase from Agaricus bisporus $(1.2 \mathrm{U}$ 
$\left.\mathrm{mg}^{-1}\right)^{18}$ was purchased from ASA Spezialenzyme. Solvents used in extraction and purification were distilled prior to use. The $\mathrm{pH}$ of the buffer was adjusted using a pH 330/SET-1 pH-meter. Analytical thin layer chromatography (TLC) was performed on precoated silica gel $60 \mathrm{~F}_{245}$ aluminium plates (Merck) with visualization under UV light. Flash chromatography was carried out on silica gel MN 60, 0.04-0.053 mm (Macherey \& Nagel). Melting points were determined on a Büchi melting point apparatus B-545 with open capillary tubes and are uncorrected. IR spectra were measured on a Perkin-Elmer Spectrum One (FTIR-spectrometer). ${ }^{1} \mathrm{H}$ and ${ }^{13} \mathrm{C}$ NMR spectra were recorded at 300 (75) $\mathrm{MHz}$ and at 500 (125) $\mathrm{MHz}$ on Varian Unity Inova instruments using DMSO- $d_{6}$ and pyridine- $d_{5}$ as solvents. The chemical shifts were referenced to the solvent signals at $\delta_{\mathrm{H} / \mathrm{C}} 2.49$ / 39.50 ppm (DMSO- $d_{6}$ ) and 8.71/149.80 ppm (pyridine- $d_{5}$ ) relative to TMS as internal standards. 2-D ROESY, gHSQC, ASAPHMQC, standard gHMBCAD, super long range gHMBCAD as well as band selective gHMBC, PIP-HSQMBC and gCOSY spectra were recorded on a Varian Unity Inova spectrometer (500 MHz). Coupling constants $J[\mathrm{~Hz}]$ were directly taken from the spectra and are not averaged. Low resolution electron impact mass spectra (EI-LRMS) and exact electron impact mass spectra (HRMS) were recorded at $70 \mathrm{eV}$ on a Finnigan MAT 95 instrument. Low resolution electron spray ionisation mass spectra (ESI-LRMS) and exact electron spray ionisation mass spectra (HRMS) were recorded on a Bruker Daltonics (micro TOFQ) instrument. The intensities are reported as percentages relative to the base peak $(I=100 \%)$.

General procedure I for the synthesis of 2,3-dihydro-2-thioxopyrimidin-4(1H)-ones $2 \mathrm{a}-\mathrm{h}$ and 2,3,6,7-tetrahydro-2-thioxo$1 \boldsymbol{H}$-cyclopenta[d] pyrimidin-4(5H)-one (2i). ${ }^{17}$ A 50 or $150 \mathrm{~mL}$ round bottomed flask with a magnetic stir bar was charged with a suspension of $\beta$-ketoester $\mathbf{6}$, thiourea (7) and $\mathrm{KOH}$ in ethanol. The mixture was stirred at $80{ }^{\circ} \mathrm{C}$ for $5 \mathrm{~h}$. Ethanol was evaporated under reduced pressure to one third of its original volume, the reaction mixture was poured into water and neutralized with 2 $\mathrm{N} \mathrm{HCl}$. The resulting mixture was left stirring overnight at rt. Filtration gave the crude product which was purified by crystallization from methanol.

Synthesis and analytical data of 2,3-dihydro-6-methyl-2-thioxopyrimidin-4(1H)-one (2a).

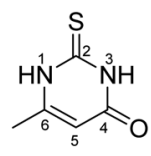

$2 a$

According to general procedure I, ethyl acetoacetate (6a) (6.50 g, $50 \mathrm{mmol})$, thiourea (7) (3.81 g, $50 \mathrm{mmol}), \mathrm{KOH} \mathrm{(2.81} \mathrm{g,}$ $50 \mathrm{mmol})$, ethanol $(80 \mathrm{~mL})$ were reacted. Work up gave 2,3dihydro-6-methyl-2-thioxopyrimidin-4(1H)-one (2a) as a white powder $(5.00 \mathrm{~g}, 70 \%), \mathrm{mp}>300{ }^{\circ} \mathrm{C}$ (lit. $\left.{ }^{24 a}>300{ }^{\circ} \mathrm{C}\right) ; R_{\mathrm{f}}=0.54$ $\left(\mathrm{CH}_{2} \mathrm{Cl}_{2} /\right.$ EtOAc $\left.=2: 1\right) ; \delta_{\mathrm{H}}\left(300 \mathrm{MHz} ;\right.$ DMSO- $\left.d_{6}\right) 2.05(3 \mathrm{H}, \mathrm{s}, 6-$ $\left.\mathrm{CH}_{3}\right), 5.66$ (1H, s, 5-H), $12.22(2 \mathrm{H}, \mathrm{br}, 1-\mathrm{H}$ and $3-\mathrm{H})$.

Synthesis and analytical data of 6-ethyl-2,3-dihydro-2-thioxopyrimidin-4(1H)-one (2b).

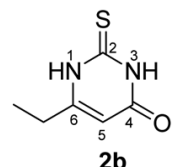

According to general procedure I, ethyl propionylacetate (6b) $(1.44 \mathrm{~g}, 10 \mathrm{mmol})$, thiourea (7) (0.76 g, $10 \mathrm{mmol}), \mathrm{KOH} \mathrm{(0.56} \mathrm{g,}$ $10 \mathrm{mmol})$, ethanol $(20 \mathrm{~mL})$ were reacted. Work up gave 6-ethyl2,3-dihydro-2-thioxopyrimidin-4(1H)-one (2b) as a white powder (0.78 g, 50\%), mp $227-229{ }^{\circ} \mathrm{C}$ (lit. ${ }^{24 a} 228.5-230.5{ }^{\circ} \mathrm{C}$ ); $R_{\mathrm{f}}=0.44$ $\left(\mathrm{CH}_{2} \mathrm{Cl}_{2} /\right.$ EtOAc $\left.=2: 1\right) ; \delta_{\mathrm{H}}\left(300 \mathrm{MHz} ; \mathrm{DMSO}-d_{6}\right) 1.08\left(3 \mathrm{H}, \mathrm{t},{ }^{3} \mathrm{~J}=\right.$ $\left.7.5 \mathrm{~Hz}, \mathrm{CH}_{3}\right), 2.35\left(2 \mathrm{H}, \mathrm{q},{ }^{3} J=7.5 \mathrm{~Hz}, \mathrm{CH}_{2}\right), 5.66(1 \mathrm{H}, \mathrm{s}, 5-\mathrm{H})$ and $12.24(2 \mathrm{H}, \mathrm{s}, 1-\mathrm{H}$ and $3-\mathrm{H}) ; \delta_{\mathrm{C}}\left(75 \mathrm{MHz}\right.$; DMSO- $\left.d_{6}\right) 11.60,24.73$, 102.04, 158.21, 161.19, 175.97.

Synthesis and analytical data of 2,3-dihydro-6-propyl-2-thioxopyrimidin-4(1H)-one (2c).

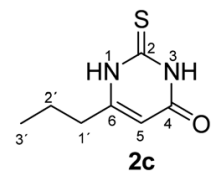

According to general procedure I, ethyl butyrylacetate (6c) (3.16 g, $20 \mathrm{mmol})$, thiourea (7) (1.52 g, $20 \mathrm{mmol})$, KOH (1.12 g, 20 $\mathrm{mmol}$ ), ethanol (20 mL) were reacted. Work up gave 2,3-dihydro-6propyl-2-thioxopyrimidin-4(1H)-one (2c) as a white powder $(1.40 \mathrm{~g}$, $41 \%$ ), mp 216-218 ${ }^{\circ} \mathrm{C}$ (lit. $\left.{ }^{24 a} 218-220{ }^{\circ} \mathrm{C}\right) ; R_{\mathrm{f}}=0.52\left(\mathrm{CH}_{2} \mathrm{Cl}_{2} /\right.$ EtOAc $=2: 1) ; \delta_{\mathrm{H}}\left(300 \mathrm{MHz} ; \mathrm{DMSO}-d_{6}\right) 0.86\left(3 \mathrm{H}, \mathrm{t},{ }^{3} J=7.4 \mathrm{~Hz}, 3^{\prime}-\mathrm{H}\right), 1.53$ $\left(2 \mathrm{H}, \mathrm{sex},{ }^{3} J=7.4 \mathrm{~Hz}, 2^{\prime}-\mathrm{H}\right), 2.30\left(2 \mathrm{H}, \mathrm{t},{ }^{3} J=7.7 \mathrm{~Hz}, 1^{\prime}-\mathrm{H}\right), 5.65$ $(1 \mathrm{H}, \mathrm{s}, 5-\mathrm{H})$ and $12.20(2 \mathrm{H}, \mathrm{s}, 1-\mathrm{H}$ and $3-\mathrm{H}) ; \delta_{\mathrm{C}}\left(75 \mathrm{MHz}\right.$; DMSO- $\left.d_{6}\right)$ 13.20, 20.50, 33.35, 102.90, 156.97, 161.17, 176.08.

Synthesis and analytical data of 2,3-dihydro-6-isopropyl-2-thioxopyrimidin-4(1H)-one (2d).<smiles>CC(C)c1cc(=O)[nH]c(=S)[nH]1</smiles>

According to general procedure I, ethyl isobutyrylacetate (6d) (1.58 g, $10 \mathrm{mmol})$, thiourea (7) (0.76 g, $10 \mathrm{mmol}), \mathrm{KOH}(0.56 \mathrm{~g}$, $10 \mathrm{mmol})$, ethanol $(20 \mathrm{~mL})$ were reacted. Work up gave 2,3dihydro-6-isopropyl-2-thioxopyrimidin-4(1H)-one (2d) as a white powder $(0.60 \mathrm{~g}, 35 \%)$, mp 176-178 ${ }^{\circ} \mathrm{C}\left(\right.$ lit. $\left.^{24 a} 179-180{ }^{\circ} \mathrm{C}\right) ; R_{\mathrm{f}}=$ $0.50\left(\mathrm{CH}_{2} \mathrm{Cl}_{2} /\right.$ EtOAc $\left.=2: 1\right) ; \delta_{\mathrm{H}}\left(300 \mathrm{MHz} ; \mathrm{DMSO}-d_{6}\right) 1.11(6 \mathrm{H}, \mathrm{d}$, $\left.{ }^{3} J=6.9 \mathrm{~Hz}, \mathrm{CH}\left(\mathrm{CH}_{3}\right)_{2}\right), 2.65\left(1 \mathrm{H}, \mathrm{sep},{ }^{3} J=6.9 \mathrm{~Hz}, \mathrm{CH}\left(\mathrm{CH}_{3}\right)_{2}\right)$, $5.65(1 \mathrm{H}, \mathrm{s}, 5-\mathrm{H})$ and $12.20(2 \mathrm{H}, \mathrm{br} \mathrm{s}, 1-\mathrm{H}$ and $3-\mathrm{H}) ; \delta_{\mathrm{C}}(75 \mathrm{MHz}$; DMSO- $\left.d_{6}\right) 20.39,30.33$, 100.33, 161.33, 162.22, 176.08.

Synthesis and analytical data of 6-tert-butyl-2,3-dihydro-2-thioxopyrimidin-4(1H)-one (2e).

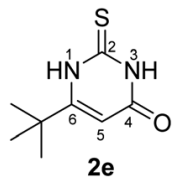


According to general procedure I, ethyl 4,4-dimethyl-3oxovalerate (6e) $(1.72 \mathrm{~g}, 10 \mathrm{mmol})$, thiourea (7) $(0.76 \mathrm{~g}, 10$ $\mathrm{mmol}), \mathrm{KOH}(0.56 \mathrm{~g}, 10 \mathrm{mmol})$, ethanol $(20 \mathrm{~mL})$ were reacted. Work up gave 6-tert-butyl-2,3-dihydro-2-thioxopyrimidin-4(1H)one (2e) as a white powder $(0.50 \mathrm{~g}, 27 \%), \mathrm{mp} 179-181{ }^{\circ} \mathrm{C}$ (lit. ${ }^{24 a}$ $\left.178-180{ }^{\circ} \mathrm{C}\right) ; R_{\mathrm{f}}=0.63\left(\mathrm{CH}_{2} \mathrm{Cl}_{2} /\right.$ EtOAc $\left.=2: 1\right) ; \delta_{\mathrm{H}}(300 \mathrm{MHz}$; DMSO- $\left.d_{6}\right) 1.21\left(9 \mathrm{H}, \mathrm{s}, \mathrm{C}\left(\mathrm{CH}_{3}\right)_{3}\right), 5.63(1 \mathrm{H}, \mathrm{s}, 5-\mathrm{H}), 11.79$ and $12.34(2 \mathrm{H}, \mathrm{s}, 1-\mathrm{H}$ and $3-\mathrm{H}) ; \delta_{\mathrm{C}}\left(75 \mathrm{MHz}\right.$; DMSO- $\left.d_{6}\right) 27.30,34.49$, 100.50, 161.16, 163.36, 176.49 .

Synthesis and analytical data of 6-trifluoromethyl-2,3-dihydro2-thioxopyrimidin-4(1H)-one (2f).

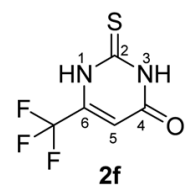

According to general procedure I, ethyl-4,4,4trifluoroacetoacetate (6f) $(1.84 \mathrm{~g}, 10 \mathrm{mmol})$, thiourea (7) $(0.76 \mathrm{~g}, 10 \mathrm{mmol}), \mathrm{KOH}(0.56 \mathrm{~g}, 10 \mathrm{mmol})$, ethanol $(20 \mathrm{~mL})$ were reacted. Work up gave 6-trifluoromethyl-2,3-dihydro-2-thioxopyrimidin-4(1H)-one (2f) as a white powder (0.69 g, 35\%), mp 246-248 ${ }^{\circ} \mathrm{C}\left(\right.$ lit. $\left.^{24 b} 247-249{ }^{\circ} \mathrm{C}\right) ; R_{\mathrm{f}}=0.50\left(\mathrm{CH}_{2} \mathrm{Cl}_{2} / \mathrm{EtOAc}=2: 1\right)$; $\delta_{\mathrm{H}}\left(300 \mathrm{MHz}\right.$; DMSO- $\left.d_{6}\right) 6.40(1 \mathrm{H}, \mathrm{s}, 5-\mathrm{H}), 12.83(1 \mathrm{H}, \mathrm{s}, 1-\mathrm{H}$ or $3-$ $\mathrm{H})$ and $13.50(1 \mathrm{H}, \mathrm{br}, 1-\mathrm{H}$ or $3-\mathrm{H}) ; \delta_{\mathrm{C}}\left(75 \mathrm{MHz}\right.$; DMSO- $\left.d_{6}\right) 105.14$ (q, $\left.{ }^{3} J_{\mathrm{C}, \mathrm{F}}=3.9 \mathrm{~Hz}, \mathrm{C}-5\right), 118.83\left(\mathrm{q},{ }^{1} J_{\mathrm{C}, \mathrm{F}}=273.7 \mathrm{~Hz}, \mathrm{CF}_{3}\right.$ ), 140.56 $\left(\mathrm{q},{ }^{2} J_{\mathrm{C}, \mathrm{F}}=36.1 \mathrm{~Hz}, \mathrm{C}-6\right), 159.84,176.82$.

Synthesis and analytical data of 2,3-dihydro-5,6-dimethyl-2thioxopyrimidin-4(1H)-one (2g).

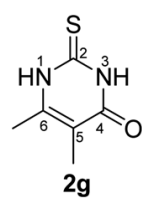

According to general procedure I, ethyl 2-methylacetoacetate (6g) (7.21 g, $50 \mathrm{mmol})$, thiourea (7) (3.81 g, $50 \mathrm{mmol}), \mathrm{KOH}$ $(2.81 \mathrm{~g}, 50 \mathrm{mmol})$, ethanol $(60 \mathrm{~mL})$ were reacted. Work up gave 2,3-dihydro-5,6-dimethyl-2-thioxopyrimidin-4(1H)-one $(\mathbf{2 g})$ as a white powder $(3.80 \mathrm{~g}, 49 \%), \mathrm{mp} 283-285^{\circ} \mathrm{C}\left(\right.$ lit. $\left.^{24 a} 283-285{ }^{\circ} \mathrm{C}\right)$; $R_{\mathrm{f}}=0.48\left(\mathrm{CH}_{2} \mathrm{Cl}_{2} /\right.$ EtOAc $\left.=2: 1\right) ; \delta_{\mathrm{H}}\left(300 \mathrm{MHz} ; \mathrm{DMSO}-d_{6}\right) 1.74$ $\left(3 \mathrm{H}, \mathrm{s}, \mathrm{CH}_{3}\right), 2.09\left(3 \mathrm{H}, \mathrm{s}, \mathrm{CH}_{3}\right)$ and $12.19(2 \mathrm{H}, \mathrm{br}, 1-\mathrm{H}$ and $3-\mathrm{H})$.

Synthesis and analytical data of 6-trifluoromethyl-2,3-dihydro5-methyl-2-thioxopyrimidin-4(1H)-one (2h).

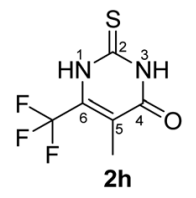

According to general procedure I, ethyl-4,4,4-trifluoro-2methylacetoacetate (6h) $(1.98 \mathrm{~g}, 10 \mathrm{mmol})$, thiourea (7) (0.76 g, $10 \mathrm{mmol}), \mathrm{KOH}(0.56 \mathrm{~g}, 10 \mathrm{mmol})$, ethanol $(15 \mathrm{~mL})$ were reacted. Work up gave 6-trifluoromethyl-2,3-dihydro-5-methyl2-thioxopyrimidin-4(1H)-one $(\mathbf{2 h})$ as a white powder $(0.60 \mathrm{~g}$, $29 \%)$, mp $244-246{ }^{\circ} \mathrm{C} ; R_{\mathrm{f}}=0.66\left(\mathrm{CH}_{2} \mathrm{Cl}_{2} /\right.$ EtOAc $\left.=2: 1\right) ; \tilde{\nu}_{\max }$ (atr)/cm ${ }^{-1} 3150(\mathrm{NH}), 2874(\mathrm{CH}), 1664(\mathrm{C}=\mathrm{O}), 1570$ and 1220; $\delta_{\mathrm{H}}\left(300 \mathrm{MHz}\right.$; DMSO- $\left.d_{6}\right) 1.93\left(3 \mathrm{H}, \mathrm{q},{ }^{5} \mathrm{~J}_{\mathrm{H}, \mathrm{F}}=3.3 \mathrm{~Hz}, 5-\mathrm{CH}_{3}\right)$ and $12.85(2 \mathrm{H}, \mathrm{br}, 1-\mathrm{H}$ and $3-\mathrm{H}) ; \delta_{\mathrm{C}}\left(75 \mathrm{MHz}\right.$; DMSO- $\left.d_{6}\right) 9.48\left(\mathrm{q},{ }^{4} J_{\mathrm{C}, \mathrm{F}}\right.$ $\left.=2.5 \mathrm{~Hz}, 5-\mathrm{CH}_{3}\right), 115.57(\mathrm{br}, \mathrm{C}-5), 119.89\left(\mathrm{q},{ }^{1} J_{\mathrm{C}, \mathrm{F}}=275.7 \mathrm{~Hz}\right.$, $\left.\mathrm{CF}_{3}\right), 135.16\left(\mathrm{q},{ }^{2} J_{\mathrm{C}, \mathrm{F}}=34.6 \mathrm{~Hz}, \mathrm{C}-6\right), 161.18,174.55$.

Synthesis and analytical data of 2,3,6,7-tetrahydro-2-thioxo- $1 \mathrm{H}$ cyclopenta[d]pyrimidin-4(5H)-one (2i).

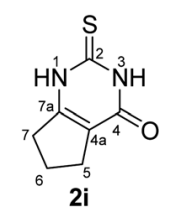

According to general procedure I, ethyl 2-oxocyclopentanecarboxylate (6i) (4.69 g, $30 \mathrm{mmol})$, thiourea (7) $(2.28 \mathrm{~g}, 30 \mathrm{mmol})$, $\mathrm{KOH}$ (1.68 g, $30 \mathrm{mmol})$, ethanol $(30 \mathrm{~mL})$ were reacted. Work up gave 2,3,6,7-tetrahydro-2-thioxo- $1 H$-cyclopenta $[d]$ pyrimidin$4(5 H)$-one $(2 \mathrm{i})$ as a white powder $(1.20 \mathrm{~g}, 24 \%), \mathrm{mp}>300{ }^{\circ} \mathrm{C}$ (lit. $\left.{ }^{24 a} 336-337{ }^{\circ} \mathrm{C}\right) ; R_{\mathrm{f}}=0.38\left(\mathrm{CH}_{2} \mathrm{Cl}_{2} /\right.$ EtOAc $\left.=2: 1\right) ; \delta_{\mathrm{H}}(300$ MHz; DMSO- $\left.d_{6}\right) 1.94$ (2H, quin, $\left.{ }^{3} J=7.3 \mathrm{~Hz}, 6-\mathrm{H}\right), 2.47$ (2H, ov. t like, $\left.{ }^{3} J=7.3 \mathrm{~Hz}, 7-\mathrm{H}\right), 2.67\left(2 \mathrm{H}, \mathrm{t},{ }^{3} J=7.6 \mathrm{~Hz}, 5-\mathrm{H}\right), 12.17$ and $12.18(2 \mathrm{H}$, br, $1-\mathrm{H}$ and $3-\mathrm{H}) ; \delta_{\mathrm{C}}\left(75 \mathrm{MHz}\right.$; DMSO- $\left.d_{6}\right) 20.78,26.60$, $31.00,115.52,156.51,159.52,175.57$.

General procedure II for the laccase-catalyzed domino reaction between catechols 1 and 2,3-dihydro-2-thioxopyrimidin$\mathbf{4}(\mathbf{1 H})$-ones 2 . A $100 \mathrm{~mL}$ round bottomed flask with a magnetic stir bar was charged with a solution or suspension of a catechol $1(0.58 \mathrm{mmol})$ and a 2,3-dihydro-2-thioxopyrimidin-4(1H)-ones 2 $(0.50 \mathrm{mmol})$ in ethanol $(2 \mathrm{~mL})$. Phosphate buffer $(0.2 \mathrm{M}, \mathrm{pH} 6$, $18 \mathrm{~mL}$ ) and laccase from A. bisporus (10 mg, $12 \mathrm{U}, 1.2 \mathrm{U} \mathrm{mg}^{-1}$ ) were added and the mixture was stirred under air at $\mathrm{rt}$ for the time given. The reaction mixture was acidified with $2 \mathrm{~N} \mathrm{HCl}$ to $\mathrm{pH} \sim 4$. The precipitated product was filtered with suction using a Buchner funnel. The filter cake was washed with water. The crude products obtained after drying exhibit a purity of $>95 \%$ $\left({ }^{1} \mathrm{H}\right.$ NMR). Analytically pure products were obtained by column filtration $\left(\mathrm{CH}_{2} \mathrm{Cl}_{2} / \mathrm{EtOAc}=1: 1\right.$ to $\mathrm{CH}_{2} \mathrm{Cl}_{2} / \mathrm{EtOAc} / \mathrm{MeOH}=$ $1: 1: 0.1)$ of the crude products.

General procedure III for the laccase-catalyzed domino reaction between catechol (1a) and 2,3-dihydro-2-thioxopyrimidin-4(1H)-ones $2 \mathrm{~g}$, h. A $100 \mathrm{~mL}$ round bottomed flask with a magnetic stir bar was charged with a solution of catechol (1a) (0.29 mmol) and 2,3-dihydro-2-thioxopyrimidin-4(1H)-ones $2 \mathrm{~g}$, h $(0.25 \mathrm{mmol})$ in ethanol $(2 \mathrm{~mL})$. Phosphate buffer $(0.2 \mathrm{M}, \mathrm{pH}$, $18 \mathrm{~mL}$ ) and laccase from A. bisporus (10 mg, $\left.12 \mathrm{U}, 1.2 \mathrm{U} \mathrm{mg}^{-1}\right)$ were added and the mixture was stirred under air at $\mathrm{rt}$ for the time given. The reaction mixture was acidified with $2 \mathrm{~N} \mathrm{HCl}$ to $\mathrm{pH} \sim 4$. The precipitated product was filtered with suction using a Buchner funnel. The filter cake was washed with water. The crude products obtained after drying exhibit a purity of $>95 \%$ $\left({ }^{1} \mathrm{H}\right.$ NMR). Analytically pure products were obtained either by acetylation or by column filtration $\left(\mathrm{CH}_{2} \mathrm{Cl}_{2} /\right.$ EtOAc $=1: 1$ to $\mathrm{CH}_{2} \mathrm{Cl}_{2} /$ EtOAc/MeOH $=1: 1: 0.1$ ) of the crude products.

Synthesis and analytical data of 7,8-dihydroxy-4H-2-methylpyrimido[2,1-b]benzothiazol-4-one (3a) and 7,8-dihydroxy-2H-4methyl-pyrimido[2,1-b]benzothiazol-2-one (4a). 
<smiles>Cc1cc(=O)n2c(n1)sc1cc(O)c(O)cc12</smiles><smiles>[14CH3]c1cc(=O)nc2sc3cc(O)c(O)cc3n12</smiles>

According to general procedure II, catechol (1a) (64 mg, 0.58 mmol), 2,3-dihydro-6-methyl-2-thioxopyrimidin-4(1H)-one (2a) (71 $\mathrm{mg}, 0.50 \mathrm{mmol}$ ), ethanol $(2 \mathrm{~mL})$, phosphate buffer $(0.2 \mathrm{M}$, $\mathrm{pH} 6.0,18 \mathrm{~mL}$ ) and laccase (12 U, $10 \mathrm{mg}$, A. bisporus) were reacted for $12 \mathrm{~h}$. Workup gave a mixture of 7,8-dihydroxy- $4 \mathrm{H}$-2methyl-pyrimido[2,1-b]benzothiazol-4-one (3a) and 7,8-dihydroxy-2H-4-methyl-pyrimido[2,1- $b]$ benzothiazol-2-one (4a) as a brown powder $(120 \mathrm{mg}, 97 \%), \mathrm{mp}>300{ }^{\circ} \mathrm{C} ; R_{\mathrm{f}}=0.27\left(\mathrm{CH}_{2} \mathrm{Cl}_{2} /\right.$ EtOAc/MeOH $=2: 2: 0.1) ; \tilde{\nu}_{\max }(\operatorname{atr}) / \mathrm{cm}^{-1} 3406(\mathrm{OH}), 3023$ $(\mathrm{CH}), 1628(\mathrm{C}=\mathrm{O}), 1510(\mathrm{C}=\mathrm{N})$ and $1185 ; \delta_{\mathrm{H}}(500 \mathrm{MHz}$; DMSO$d_{6}$ ) of 3a $2.26\left(3 \mathrm{H}, \mathrm{s}, 2-\mathrm{CH}_{3}\right), 6.17(1 \mathrm{H}, \mathrm{s}, 3-\mathrm{H}), 7.30(1 \mathrm{H}, \mathrm{s}, 9-\mathrm{H})$, $8.44(1 \mathrm{H}, \mathrm{s}, 6-\mathrm{H})$ and $9.66\left(2 \mathrm{H}\right.$, ov. br, 7,8-OH); $\delta_{\mathrm{H}}(500 \mathrm{MHz}$; DMSO- $\left.d_{6}\right)$ of $4 \mathrm{a} 2.73\left(3 \mathrm{H}, \mathrm{s}, 4-\mathrm{CH}_{3}\right), 6.07(1 \mathrm{H}, \mathrm{s}, 3-\mathrm{H}), 7.25(1 \mathrm{H}, \mathrm{s}$, 9-H), $7.52(1 \mathrm{H}, \mathrm{s}, 6-\mathrm{H})$ and $9.66\left(2 \mathrm{H}\right.$, ov. br, 7,8-OH); $\delta_{\mathrm{C}}(125$ MHz; DMSO- $d_{6}$ ) of 3a $23.10\left(2-\mathrm{CH}_{3}\right), 105.68$ (C-3), 106.38 (C-6), 108.29 (C-9), 113.21 (C-9a), 128.12 (C-5a), 144.96 (C-7), 145.65 (C-8), 159.97 (C-4), $161.71(\mathrm{C}-10 \mathrm{a})$ and $161.99(\mathrm{C}-2) ; \delta_{\mathrm{C}}(125 \mathrm{MHz}$; DMSO- $d_{6}$ ) of $4 \mathrm{a} 21.15\left(4-\mathrm{CH}_{3}\right), 104.76$ (C-6), 108.97 (C-9), 110.80 (C-3), 112.65 (C-9a), 128.82 (C-5a), 144.68 (C-8), 145.25 (C-7), 148.31 (C-4), 164.60 (C-10a) and 166.32 (C-2); MS (EI-70 eV) $\mathrm{m} /$ $z 248\left(\mathrm{M}^{+}, 100 \%\right), 220$ (35) and 181 (15); HRMS calcd for $\mathrm{C}_{11} \mathrm{H}_{8} \mathrm{~N}_{2} \mathrm{O}_{3} \mathrm{~S}$ (248.0256), found 248.0253 .

Synthesis and analytical data of 7,8-dihydroxy-4H-2-ethyl-pyrimido[2,1-b]benzothiazol-4-one (3b) and 7,8-dihydroxy-2H-4-ethylpyrimido[2,1-b]benzothiazol-2-one (4b).

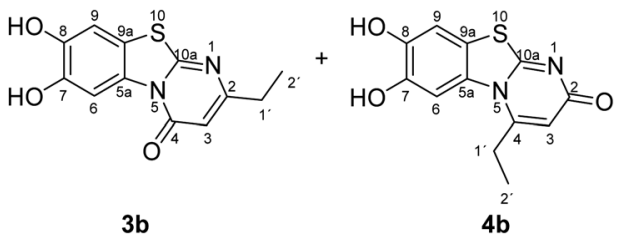

According to general procedure II, catechol (1a) (64 mg, 0.58 mmol), 6-ethyl-2,3-dihydro-2-thioxopyrimidin-4(1H)-one (2b) (78 $\mathrm{mg}, 0.50 \mathrm{mmol})$, ethanol $(2 \mathrm{~mL})$, phosphate buffer $(0.2 \mathrm{M}$, $\mathrm{pH} 6.0,18 \mathrm{~mL}$ ) and laccase (12 U, $10 \mathrm{mg}$, A. bisporus) were reacted for $12 \mathrm{~h}$. Workup gave a mixture of 7,8-dihydroxy- $4 \mathrm{H}$-2ethyl-pyrimido[2,1- $b]$ benzothiazol-4-one (3b) and 7,8-dihydroxy$2 \mathrm{H}$-4-ethyl-pyrimido[2,1- $b]$ benzothiazol-2-one (4b) as a brown powder (124 mg, 95\%), mp 298-300 ${ }^{\circ} \mathrm{C} ; R_{\mathrm{f}}=0.27\left(\mathrm{CH}_{2} \mathrm{Cl}_{2} / \mathrm{EtOAc}\right.$ $=2: 1) ; \tilde{\nu}_{\max }(\mathrm{atr}) / \mathrm{cm}^{-1} 3400(\mathrm{OH}), 2979(\mathrm{CH}), 1625(\mathrm{C}=\mathrm{O})$, 1512 and 1299; $\delta_{\mathrm{H}}\left(500 \mathrm{MHz}\right.$; DMSO- $\left.d_{6}\right)$ of $\mathbf{3 b} 1.17\left(3 \mathrm{H}, \mathrm{t},{ }^{3} \mathrm{~J}=\right.$ $\left.7.5 \mathrm{~Hz}, 2^{\prime}-\mathrm{H}\right), 2.54\left(2 \mathrm{H}, \mathrm{q},{ }^{3} J=7.5 \mathrm{~Hz}, 1^{\prime}-\mathrm{H}\right), 6.16(1 \mathrm{H}, \mathrm{s}, 3-\mathrm{H})$, $7.30(1 \mathrm{H}, \mathrm{s}, 9-\mathrm{H}), 8.45(1 \mathrm{H}, \mathrm{s}, 6-\mathrm{H})$ and $9.65(2 \mathrm{H}, \mathrm{ov} . \mathrm{br}, 7,8-\mathrm{OH})$; $\delta_{\mathrm{H}}\left(500 \mathrm{MHz}\right.$; DMSO- $\left.d_{6}\right)$ of $\mathbf{4 b} 1.27\left(3 \mathrm{H}, \mathrm{t},{ }^{3} J=7.1 \mathrm{~Hz}, 2^{\prime}-\mathrm{H}\right), 3.09$ $\left(2 \mathrm{H}, \mathrm{q},{ }^{3} J=7.1 \mathrm{~Hz}, 1^{\prime}-\mathrm{H}\right), 6.02(1 \mathrm{H}, \mathrm{s}, 3-\mathrm{H}), 7.25(1 \mathrm{H}, \mathrm{s}, 9-\mathrm{H}), 7.49$ $(1 \mathrm{H}, \mathrm{s}, 6-\mathrm{H})$ and $9.65(2 \mathrm{H}, \mathrm{br}, 7,8-\mathrm{OH}) ; \delta_{\mathrm{C}}\left(125 \mathrm{MHz}\right.$; DMSO- $\left.d_{6}\right)$ of 3b 12.25 (C-2'), $29.56\left(\mathrm{C}-1^{\prime}\right), 104.36$ (C-3), 106.37 (C-6), 108.30 (C9), 113.24 (C-9a), 128.09 (C-5a), 144.94 (C-7), 145.65 (C-8), 160.25 $(\mathrm{C}-4), 161.82$ (C-10a), $166.68(\mathrm{C}-2)$; $\delta_{\mathrm{C}}\left(125 \mathrm{MHz}\right.$; DMSO- $\left.d_{6}\right)$ of $4 \mathbf{b}$ $11.57\left(\mathrm{C}-2^{\prime}\right), 25.84\left(\mathrm{C}-1^{\prime}\right), 104.93$ (C-6), 108.52 (C-3), 108.96 (C-9),
112.73 (C-9a), 128.40 (C-5a), 144.63 (C-8), 145.33 (C-7), 153.26 (C-4), 164.91 (C-10a) and 166.35 (C-2); MS (EI-70 eV) m/z $262\left(\mathrm{M}^{+}\right.$, $100 \%), 263\left([\mathrm{M}+\mathrm{H}]^{+}, 37\right)$ and 219 (19); HRMS calcd for $\mathrm{C}_{12} \mathrm{H}_{10} \mathrm{~N}_{2} \mathrm{O}_{3} \mathrm{~S}$ (262.0412), found 262.0413.

Synthesis and analytical data of 7,8-dihydroxy-4H-2-propylpyrimido[2,1-b]benzothiazol-4-one (3c) and 7,8-dihydroxy-2H-4propyl-pyrimido[2,1-b]benzothiazol-2-one (4c).

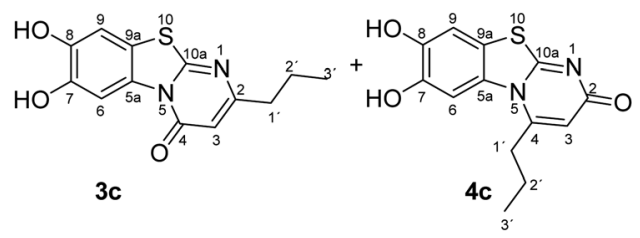

According to general procedure II, catechol (1a) (64 mg, 0.58 mmol), 2,3-dihydro-6-propyl-2-thioxopyrimidin-4(1H)-one (2c) ( $85 \mathrm{mg}, 0.50 \mathrm{mmol})$, ethanol $(2 \mathrm{~mL})$, phosphate buffer $(0.2 \mathrm{M}$, $\mathrm{pH} 6.0,18 \mathrm{~mL}$ ) and laccase (12 U, $10 \mathrm{mg}$, A. bisporus) were reacted for $18 \mathrm{~h}$. Workup gave a mixture of 7,8-dihydroxy-4H-2propyl-pyrimido[2,1-b] benzothiazol-4-one (3c) and 7,8-dihydroxy-2H-4-propyl-pyrimido[2,1- $b]$ benzothiazol-2-one $(\mathbf{4 c})$ as a brown powder $(130 \mathrm{mg}, 94 \%), \mathrm{mp} 258-260{ }^{\circ} \mathrm{C} ; R_{\mathrm{f}}=0.27$ $\left(\mathrm{CH}_{2} \mathrm{Cl}_{2} /\right.$ EtOAc $\left.=2: 1\right) ; \tilde{\nu}_{\max }(\operatorname{atr}) / \mathrm{cm}^{-1} 3310(\mathrm{OH}), 2960(\mathrm{CH})$, $1625(\mathrm{C}=\mathrm{O}), 1453$ and $1307 ; \delta_{\mathrm{H}}\left(500 \mathrm{MHz}\right.$; DMSO- $\left.d_{6}\right)$ of $3 \mathrm{c} 0.89$ $\left(3 \mathrm{H}, \mathrm{t},{ }^{3} J=7.3 \mathrm{~Hz}, 3^{\prime}-\mathrm{H}\right), 1.65$ (2H, ov., $\left.2^{\prime}-\mathrm{H}\right), 2.49$ (2H, ov., $\left.1^{\prime}-\mathrm{H}\right)$, $6.15\left(1 \mathrm{H}\right.$, br s, 3-H), $7.30(1 \mathrm{H}, \mathrm{s}, 9-\mathrm{H})$ and $8.45(1 \mathrm{H}, \mathrm{s}, 6-\mathrm{H}) ; \delta_{\mathrm{H}}$ $\left(500 \mathrm{MHz}\right.$; DMSO- $\left.d_{6}\right)$ of $4 \mathrm{c} 1.04\left(3 \mathrm{H}, \mathrm{t},{ }^{3} J=7.1 \mathrm{~Hz}, 3^{\prime}-\mathrm{H}\right), 1.65$ $\left(2 \mathrm{H}\right.$, ov. sex, $\left.{ }^{3} J=7.7 \mathrm{~Hz}, 2^{\prime}-\mathrm{H}\right), 3.00\left(2 \mathrm{H}, \mathrm{t},{ }^{3} J=7.5 \mathrm{~Hz}, 1^{\prime}-\mathrm{H}\right), 6.03$ $\left(1 \mathrm{H}\right.$, br s, 3-H), $7.25(1 \mathrm{H}, \mathrm{s}, 9-\mathrm{H})$ and $7.41(1 \mathrm{H}, \mathrm{s}, 6-\mathrm{H}) ; \delta_{\mathrm{C}}(125$ MHz; DMSO- $\left.d_{6}\right)$ of 3c 13.50 (C-3'), 20.87 (C-2'), $38.26\left(\mathrm{C}-1^{\prime}\right)$, 105.26 (C-3), 106.39 (C-6), 108.29 (C-9), 113.24 (C-9a), 128.09 (C5a), 144.95 (C-7), 145.66 (C-8), 160.10 (C-4), 161.84 (C-10a), $165.30(\mathrm{C}-2) ; \delta_{\mathrm{C}}\left(125 \mathrm{MHz}\right.$; DMSO- $\left.d_{6}\right)$ of $4 \mathrm{c} 13.14\left(\mathrm{C}-3^{\prime}\right), 20.09$ (C-2'), 34.20 (C-1'), 104.63 (C-6), 109.00 (C-9), 109.73 (C-3), 112.73 (C-9a), 128.28 (C-5a), 144.72 (C-8), 145.38 (C-7), 151.48 (C-4), 164.98 (C-10a), 166.24 (C-2); MS (ESI) $m / z 299\left([\mathrm{M}+\mathrm{Na}]^{+}\right.$, $100 \%)$ and $277\left([\mathrm{M}+\mathrm{H}]^{+}, 35\right)$; HRMS calcd for $\mathrm{C}_{13} \mathrm{H}_{12} \mathrm{~N}_{2} \mathrm{O}_{3} \mathrm{~S}+\mathrm{Na}$ (299.0461), found 299.0457.

Synthesis and analytical data of 7,8-dihydroxy-4H-2-isopropylpyrimido[2,1-b]benzothiazol-4-one (3d) and 7,8-dihydroxy-2H-4isopropyl-pyrimido[2,1-b]benzothiazol-2-one (4d).

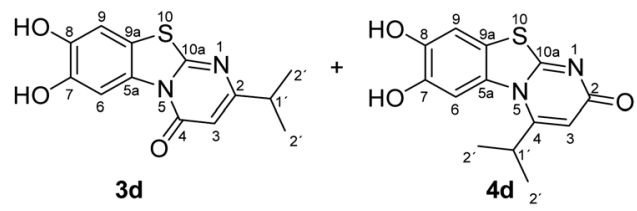

According to general procedure II, catechol (1a) (64 mg, 0.58 mmol), 2,3-dihydro-6-isopropyl-2-thioxopyrimidin-4(1H)-one (2d) $(85 \mathrm{mg}, 0.50 \mathrm{mmol})$, ethanol $(2 \mathrm{~mL})$, phosphate buffer $(0.2 \mathrm{M}, \mathrm{pH} 6.0,18 \mathrm{~mL})$ and laccase (12 U, $10 \mathrm{mg}$, A. bisporus) were reacted for $13 \mathrm{~h}$. Workup gave a mixture of 7,8-dihydroxy4H-2-isopropyl-pyrimido[2,1- $b]$ benzothiazol-4-one (3d) and 7,8-dihydroxy-2H-4-isopropyl-pyrimido[2,1- $b]$ benzothiazol-2-one (4d) as a brown powder (131 mg, 95\%); mp 250-252 ${ }^{\circ} \mathrm{C} ; R_{\mathrm{f}}=0.36$ $\left(\mathrm{CH}_{2} \mathrm{Cl}_{2} /\right.$ EtOAc $\left.=0.1: 1\right) ; \tilde{\nu}_{\max }(\operatorname{atr}) / \mathrm{cm}^{-1} 3350(\mathrm{OH}), 2962(\mathrm{CH})$, 
$1636(\mathrm{C}=\mathrm{O}), 1517$ and $1234 ; \delta_{\mathrm{H}}\left(500 \mathrm{MHz}\right.$; DMSO- $\left.d_{6}\right)$ of $3 \mathrm{~d} 1.17$ $\left(6 \mathrm{H}, \mathrm{d},{ }^{3} J=6.9 \mathrm{~Hz}, 2^{\prime}-\mathrm{H}\right), 2.77\left(1 \mathrm{H}, \mathrm{sep},{ }^{3} J=6.8 \mathrm{~Hz}, 1^{\prime}-\mathrm{H}\right), 6.15$ $(1 \mathrm{H}, \mathrm{s}, 3-\mathrm{H}), 7.35(1 \mathrm{H}, \mathrm{s}, 9-\mathrm{H}), 8.44(1 \mathrm{H}, \mathrm{s}, 6-\mathrm{H})$ and $9.77(2 \mathrm{H}, \mathrm{ov}$. br, 7,8-OH); $\delta_{\mathrm{H}}\left(500 \mathrm{MHz}\right.$; DMSO- $\left.d_{6}\right)$ of 4d $1.32\left(6 \mathrm{H}, \mathrm{d},{ }^{3} \mathrm{~J}=\right.$ $\left.6.3 \mathrm{~Hz}, 2^{\prime}-\mathrm{H}\right), 3.64$ (1H, ov., $\left.1^{\prime}-\mathrm{H}\right), 6.08$ (1H, s, 3-H), 7.30 (1H, s, 9$\mathrm{H}), 7.68(1 \mathrm{H}, \mathrm{s}, 6-\mathrm{H})$ and $9.77\left(2 \mathrm{H}\right.$, ov. br, 7,8-OH); $\delta_{\mathrm{C}}(125 \mathrm{MHz}$; DMSO- $d_{6}$ ) of 3d 21.19 (C-2'), 34.65 (C-1'), 103.22 (C-3), 106.53 (C6), 108.34 (C-9), 113.20 (C-9a), 128.02 (C-5a), 144.98 (C-7), 145.77 (C-8), 160.42 (C-4), 161.90 (C-10a) and $170.33(\mathrm{C}-2)$; $\delta_{\mathrm{C}}(125 \mathrm{MHz}$; DMSO- $d_{6}$ ) of 4d 21.48 (C-2'), 28.59 (C-1'), 105.33 (C-6), 106.43 (C3), 109.02 (C-9), 112.65 (C-9a), 128.00 (C-5a), 144.81 (C-8), 145.64 (C-7), 158.10 (C-4), 165.25 (C-10a), 166.53 (C-2); MS (ESI) m/z 315 $\left([\mathrm{M}+\mathrm{K}]^{+}, 20 \%\right), 277\left([\mathrm{M}+\mathrm{H}]^{+}, 100\right), 249$ (8); HRMS calcd for $\mathrm{C}_{13} \mathrm{H}_{12} \mathrm{~N}_{2} \mathrm{O}_{3} \mathrm{~S}+\mathrm{H}$ (277.0641), found 277.0615. Column filtration using the eluent $\mathrm{CH}_{2} \mathrm{Cl}_{2} /$ EtOAc $=1: 1$ gave $3 \mathbf{d}$ in pure form; $\mathrm{mp}$ 259-261 ${ }^{\circ} \mathrm{C}$.

Synthesis and analytical data of 7,8-dihydroxy-4H-2-tert-butylpyrimido[2,1-b]benzothiazol-4-one (3e).

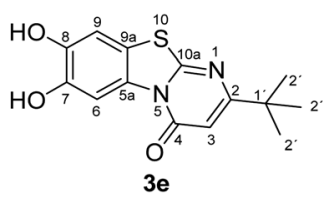

According to general procedure II, catechol (1a) (64 mg, 0.58 mmol), 6-tert-butyl-2,3-dihydro-2-thioxopyrimidin-4( $1 \mathrm{H})$-one (2e) (92 $\mathrm{mg}, 0.50 \mathrm{mmol})$, ethanol $(2 \mathrm{~mL})$, phosphate buffer (0.2 M, pH 6.0, $18 \mathrm{~mL}$ ) and laccase (12 U, $10 \mathrm{mg}$, A. bisporus) were reacted for $16 \mathrm{~h}$. Workup gave 7,8-dihydroxy- $4 \mathrm{H}$-2-tertbutyl-pyrimido[2,1- $b]$ benzothiazol-4-one (3e) as a brown powder (140 mg, 97\%), $\mathrm{mp}>300{ }^{\circ} \mathrm{C} ; R_{\mathrm{f}}=0.38\left(\mathrm{CH}_{2} \mathrm{Cl}_{2} / \mathrm{EtOAc}=0.1: 1\right)$; $\tilde{\nu}_{\max }(\mathrm{atr}) / \mathrm{cm}^{-1} 3295(\mathrm{OH}), 2954(\mathrm{CH}), 1638(\mathrm{C}=\mathrm{O}), 1546$ and $1185 ; \delta_{\mathrm{H}}\left(500 \mathrm{MHz}\right.$; DMSO- $\left.d_{6}\right) 1.23$ (9H, s, 2'-H), 6.21 (1H, s, 3$\mathrm{H}), 7.31(1 \mathrm{H}, \mathrm{s}, 9-\mathrm{H}), 8.44(1 \mathrm{H}, \mathrm{s}, 6-\mathrm{H})$ and $9.75(2 \mathrm{H}, \mathrm{br}, 7,8-\mathrm{OH})$; $\delta_{\mathrm{C}}\left(125 \mathrm{MHz}\right.$; DMSO- $\left.d_{6}\right) 28.67\left(\mathrm{C}-2^{\prime}\right), 36.78\left(\mathrm{C}-1^{\prime}\right), 102.08(\mathrm{C}-3)$, 106.42 (C-6), 108.32 (C-9), 113.22 (C-9a), 127.90 (C-5a), 144.94 (C-7), 145.73 (C-8), 160.52 (C-4), 161.36 (C-10a) and 172.33 (C-2); MS (ESI) $m / z 329\left([\mathrm{M}+\mathrm{K}]^{+}, 31 \%\right)$ and $291\left([\mathrm{M}+\mathrm{H}]^{+}, 100\right)$; HRMS calcd for $\mathrm{C}_{14} \mathrm{H}_{14} \mathrm{~N}_{2} \mathrm{O}_{3} \mathrm{~S}+\mathrm{H}$ (291.0798), found 291.0802.

Synthesis and analytical data of 7,8-dihydroxy-4H-2-trifluoromethyl-pyrimido[2,1-b]benzothiazol-4-one (3f).

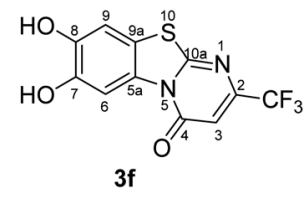

According to general procedure II, catechol (1a) (64 mg, 0.58 mmol), 6-trifluoromethyl-2,3-dihydro-2-thioxopyrimidin-4 $(1 H)$ one $(\mathbf{2 g})$ (98 $\mathrm{mg}, 0.50 \mathrm{mmol})$, ethanol $(2 \mathrm{~mL})$, phosphate buffer $(0.2 \mathrm{M}, \mathrm{pH} 6.0,18 \mathrm{~mL})$ and laccase $(12 \mathrm{U}, 10 \mathrm{mg}$, A. bisporus $)$ were reacted for $16 \mathrm{~h}$. Workup gave 7,8-dihydroxy-4H-2-trifluoromethyl-pyrimido[2,1- $b$ ]benzothiazol-4-one (3f) as a brown powder (118 mg, 78\%), $\mathrm{mp}>300{ }^{\circ} \mathrm{C} ; R_{\mathrm{f}}=0.31$ (cyclohexane/ EtOAc $=1: 1) ; \tilde{\nu}_{\max }(\operatorname{atr}) / \mathrm{cm}^{-1} 3408(\mathrm{OH}), 1654(\mathrm{C}=\mathrm{O}), 1526$ $(\mathrm{C}=\mathrm{N})$ and $1151 ; \delta_{\mathrm{H}}\left(500 \mathrm{MHz}\right.$; DMSO- $\left.d_{6}\right) 6.79(1 \mathrm{H}, \mathrm{s}, 3-\mathrm{H}), 7.42$
(1H, s, 9-H), $8.47(1 \mathrm{H}, \mathrm{s}, 6-\mathrm{H}), 9.82$ and $9.90(2 \mathrm{H}, 2 \mathrm{~s}, 7,8-\mathrm{OH}) ; \delta_{\mathrm{C}}$ $\left(125 \mathrm{MHz}\right.$; DMSO- $d_{6}$ ) 105.31 (q, $\left.{ }^{3} J_{\mathrm{C}, \mathrm{F}}=3.1 \mathrm{~Hz}, \mathrm{C}-3\right), 106.33(\mathrm{C}-6)$, 108.35 (C-9), 114.19 (C-9a), 120.78 (q, ${ }^{1} J_{\mathrm{C}, \mathrm{F}}=273.0 \mathrm{~Hz}, \mathrm{CF}_{3}$ ), 127.82 (C-5a), 145.42 (C-7), 146.41 (C-8), 148.25 (q, ${ }^{2} J_{\mathrm{C}, \mathrm{F}}=$ $34.4 \mathrm{~Hz}, \mathrm{C}-2$ ), 159.47 (C-4), 164.29 (C-10a); MS (ESI) m/z 341 ([M $\left.+\mathrm{K}]^{+}, 49 \%\right), 303\left([\mathrm{M}+\mathrm{H}]^{+}, 100\right)$ and 283 (73); HRMS calcd for $\mathrm{C}_{11} \mathrm{H}_{5} \mathrm{~F}_{3} \mathrm{~N}_{2} \mathrm{O}_{3} \mathrm{~S}+\mathrm{H}$ (303.0046), found 303.0046.

Synthesis and analytical data of 7,8-dihydroxy-4H-2,3-dimethylpyrimido[2,1-b]benzothiazol-4-one (3g) and 7,8-dihydroxy-2H-3,4dimethyl-pyrimido[2,1-b]benzothiazol-2-one (4g).

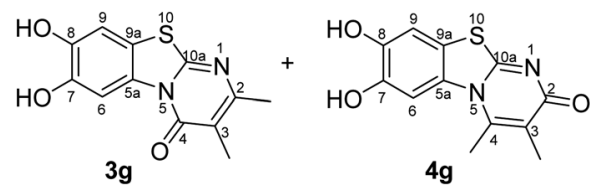

According to general procedure III, catechol (1a) (32 mg, 0.29 mmol), 2,3-dihydro-5,6-dimethyl-2-thioxopyrimidin-4( $1 H$ )-one (2g) (39 mg, $0.25 \mathrm{mmol}$ ), ethanol (2 mL), phosphate buffer (0.2 M, pH 6.0, $18 \mathrm{~mL}$ ) and laccase (12 U, $10 \mathrm{mg}$, A. bisporus) were reacted for $28 \mathrm{~h}$. Workup gave a mixture of 7,8-dihydroxy4H-2,3-dimethyl-pyrimido[2,1-b]benzothiazol-4-one (3g) and 7,8-dihydroxy- $2 \mathrm{H}$-3,4-dimethyl-pyrimido[2,1- $b]$ benzothiazol-2one (4g) as a brown powder (58 $\mathrm{mg}, 89 \%), \mathrm{mp}>300{ }^{\circ} \mathrm{C} ; R_{\mathrm{f}}=0.46$ $\left(\mathrm{CH}_{2} \mathrm{Cl}_{2} /\right.$ EtOAc $\left.=1: 1\right) ; \tilde{\nu}_{\max }(\operatorname{atr}) / \mathrm{cm}^{-1} 3352(\mathrm{OH}), 3023(\mathrm{CH})$, $1631(\mathrm{C}=\mathrm{O}), 1488$ and $1185 ; \delta_{\mathrm{H}}\left(500 \mathrm{MHz}\right.$; DMSO- $\left.d_{6}\right)$ of $3 \mathrm{~g} 2.03$ $\left(3 \mathrm{H}, \mathrm{s}, 3-\mathrm{CH}_{3}\right), 2.28\left(3 \mathrm{H}, \mathrm{s}, 2-\mathrm{CH}_{3}\right), 7.28(1 \mathrm{H}, \mathrm{s}, 9-\mathrm{H}), 8.48(1 \mathrm{H}, \mathrm{s}$, $6-\mathrm{H})$ and $9.61(2 \mathrm{H}, \mathrm{ov} . \mathrm{br}, 7,8-\mathrm{OH}) ; \delta_{\mathrm{H}}\left(500 \mathrm{MHz}\right.$; DMSO- $\left.d_{6}\right)$ of $4 \mathrm{~g}$ $2.00\left(3 \mathrm{H}, \mathrm{s}, 3-\mathrm{CH}_{3}\right), 2.73\left(3 \mathrm{H}, \mathrm{s}, 4-\mathrm{CH}_{3}\right), 7.25(1 \mathrm{H}, \mathrm{s}, 9-\mathrm{H}), 7.58$ $(1 \mathrm{H}, \mathrm{s}, 6-\mathrm{H})$ and $9.61\left(2 \mathrm{H}\right.$, ov. br, 7,8-OH); $\delta_{\mathrm{C}}(125 \mathrm{MHz}$; DMSO$d_{6}$ ) of $3 \mathrm{~g} 10.98\left(3-\mathrm{CH}_{3}\right), 21.71\left(2-\mathrm{CH}_{3}\right), 106.46$ (C-6), 108.29 (C-9), 112.82 (C-3), 113.33 (C-9a), 128.12 (C-5a), 144.77 (C-7), 145.52 (C-8), 157.37 (C-2), 157.83 (C-10a) and $160.46(\mathrm{C}-4) ; \delta_{\mathrm{C}}(125 \mathrm{MHz}$; DMSO- $\left.d_{6}\right)$ of $4 \mathrm{~g} 12.01\left(3-\mathrm{CH}_{3}\right), 17.97\left(4-\mathrm{CH}_{3}\right), 105.06$ (C-6), 108.99 (C-9), 112.76 (C-9a), 116.70 (C-3), 129.21 (C-5a), 144.00 (C-4), 144.49 (C-8), 145.02 (C-7), 162.86 (C-10a) and 166.21 (C-2); analytically pure product was obtained by acetylation; MS (ESI) $m / z 369\left([\mathrm{M}+\mathrm{Na}]^{+}, 93 \%\right), 347\left([\mathrm{M}+\mathrm{H}]^{+}, 49\right), 305$ (53) and 263 (100); HRMS calcd for $\mathrm{C}_{16} \mathrm{H}_{14} \mathrm{~N}_{2} \mathrm{O}_{5} \mathrm{~S}+\mathrm{Na}$ (369.0516), found 369.0522 .

Synthesis and analytical data of 7,8-dihydroxy-4H-3-methyl-2trifluoromethyl-pyrimido[2,1-b]benzothiazol-4-one (3h).

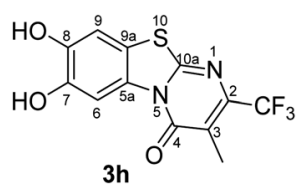

According to general procedure III, catechol (1a) (32 mg, 0.29 mmol), 6-trifluoromethyl-2,3-dihydro-5-methyl-2-thioxopyrimidin-4(1H)-one (2h) $(52.5 \mathrm{mg}, 0.25 \mathrm{mmol})$, ethanol $(2 \mathrm{~mL})$, phosphate buffer $(0.2 \mathrm{M}, \mathrm{pH} 6.0,18 \mathrm{~mL})$ and laccase $(12 \mathrm{U}$, $10 \mathrm{mg}$, A. bisporus) were reacted for $17 \mathrm{~h}$. Workup gave 7,8dihydroxy- $4 H$-2-trifluoromethyl-pyrimido[2,1- $b]$ benzothiazol-4one (3h) as a brown powder $(75 \mathrm{mg}, 95 \%), \mathrm{mp}>300^{\circ} \mathrm{C} ; R_{\mathrm{f}}=0.49$ $\left(\mathrm{CH}_{2} \mathrm{Cl}_{2} /\right.$ EtOAc $\left.=2: 1\right) ; \tilde{\nu}_{\max }(\operatorname{atr}) / \mathrm{cm}^{-1} 3533(\mathrm{OH}), 3120(\mathrm{CH})$, $1632(\mathrm{C}=\mathrm{O}), 1531(\mathrm{C}=\mathrm{N})$ and $1224 ; \delta_{\mathrm{H}}\left(500 \mathrm{MHz} ; \mathrm{DMSO}-d_{6}\right)$ 
$2.20\left(3 \mathrm{H}, \mathrm{q},{ }^{5} \mathrm{~J}_{\mathrm{H}, \mathrm{F}}=2.2 \mathrm{~Hz}, 3-\mathrm{CH}_{3}\right), 7.39(1 \mathrm{H}, \mathrm{s}, 9-\mathrm{H}), 8.49(1 \mathrm{H}, \mathrm{s}$, 6-H) and 9.85 (2H, br, 7,8-OH); $\delta_{\mathrm{C}}\left(125 \mathrm{MHz}\right.$; DMSO- $\left.d_{6}\right) 10.18$ (q, ${ }^{4} J_{\mathrm{C}, \mathrm{F}}=2.2 \mathrm{~Hz}, 3-\mathrm{CH}_{3}$ ), 106.40 (C-6), 108.36 (C-9), 114.29 (C-9a), 116.29 (br s, C-3), 121.78 (q, ${ }^{1} J_{\mathrm{C}, \mathrm{F}}=274.6 \mathrm{~Hz}, \mathrm{CF}_{3}$ ), 127.59 (C5a), 143.73 (q, $\left.{ }^{2} J_{\mathrm{C}, \mathrm{F}}=33.0 \mathrm{~Hz}, \mathrm{C}-2\right), 145.22$ (C-7), 146.27 (C-8), $159.79(\mathrm{C}-10 \mathrm{a})$ and $160.82(\mathrm{C}-4)$; MS (ESI) $\mathrm{m} / \mathrm{z} 355\left([\mathrm{M}+\mathrm{K}]^{+}\right.$, $72 \%), 317\left([\mathrm{M}+\mathrm{H}]^{+}, 74\right), 297$ (100) and 249 (60); HRMS calcd for $\mathrm{C}_{12} \mathrm{H}_{7} \mathrm{~F}_{3} \mathrm{~N}_{2} \mathrm{O}_{3} \mathrm{~S}+\mathrm{H}$ (317.0202), found 317.0193.

Synthesis and analytical data of 2-(4,5-dihydroxy-2-methylphenylthio)-6-methylpyrimidin-4(3H)-one (5a).

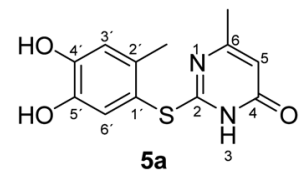

According to general procedure II, 4-methylcatechol (1b) (72 mg, $0.58 \mathrm{mmol}$ ), 2,3-dihydro-6-methyl-2-thioxopyrimidin4(1H)-one (2a) (71 mg, $0.50 \mathrm{mmol}$ ), ethanol ( $2 \mathrm{~mL})$, phosphate buffer $(0.2 \mathrm{M}, \mathrm{pH} 6.0,18 \mathrm{~mL})$ and laccase $(12 \mathrm{U}, 10 \mathrm{mg}, A$. bisporus) were reacted for $12 \mathrm{~h}$. Workup gave 2-(4,5-dihydroxy2-methylphenylthio)-6-methylpyrimidin-4(3H)-one (5a) as a pale yellow powder (108 $\mathrm{mg}, 82 \%), \mathrm{mp} 213-215{ }^{\circ} \mathrm{C} ; R_{\mathrm{f}}=0.27$ $\left(\mathrm{CH}_{2} \mathrm{Cl}_{2} / \mathrm{EtOAc} / \mathrm{MeOH}=3: 3: 0.1\right) ; \tilde{\nu}_{\max }(\operatorname{atr}) / \mathrm{cm}^{-1} 3406(\mathrm{OH})$, $2916(\mathrm{CH}), 1644(\mathrm{C}=\mathrm{O}), 1508$ and 1264; $\delta_{\mathrm{H}}(500 \mathrm{MHz}$; pyridine- $\left.d_{5}\right) 2.13\left(3 \mathrm{H}, \mathrm{s}, 6-\mathrm{CH}_{3}\right), 2.43\left(3 \mathrm{H}, \mathrm{s}, 2^{\prime}-\mathrm{CH}_{3}\right), 6.29(1 \mathrm{H}, \mathrm{s}, 5-$ $\mathrm{H}), 7.23\left(1 \mathrm{H}, \mathrm{s}, 3^{\prime}-\mathrm{H}\right)$ and $7.69\left(1 \mathrm{H}, \mathrm{s}, 6^{\prime}-\mathrm{H}\right) ; \delta_{\mathrm{C}}(125 \mathrm{MHz}$; pyridine- $\left.d_{5}\right) 20.40\left(2^{\prime}-\mathrm{CH}_{3}\right), 23.67\left(6-\mathrm{CH}_{3}\right), 105.59(\mathrm{C}-5), 116.82$ $\left(\mathrm{C}-1^{\prime}\right), 118.95\left(\mathrm{C}-3^{\prime}\right), 125.04\left(\mathrm{C}-6^{\prime}\right), 135.40$ (ov., C-2'), 145.63 (C$5^{\prime}$ ), $149.64\left(\mathrm{C}-4^{\prime}\right), 166.69$ (C-6), 167.13 (C-2) and 167.87 (C-4); MS (ESI) $m / z 287\left([\mathrm{M}+\mathrm{Na}]^{+}, 100 \%\right), 265\left([\mathrm{M}+\mathrm{H}]^{+}, 75\right)$ and 143 (60); HRMS calcd for $\mathrm{C}_{12} \mathrm{H}_{12} \mathrm{~N}_{2} \mathrm{O}_{3} \mathrm{~S}+\mathrm{H}$ (265.0641), found 265.0643.

Synthesis and analytical data of 2-(4,5-dihydroxy-2-methylphenylthio)-6-propylpyrimidin-4(3H)-one (5b).

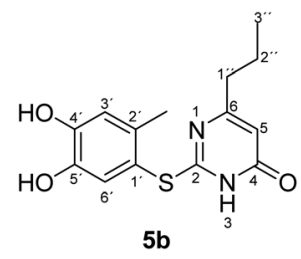

According to general procedure II, 4-methylcatechol (1b) (72 mg, $0.58 \mathrm{mmol}$ ), 2,3-dihydro-6-propyl-2-thioxopyrimidin$4(1 \mathrm{H})$-one (2c) ( $85 \mathrm{mg}, 0.50 \mathrm{mmol})$, ethanol ( $2 \mathrm{~mL})$, phosphate buffer $(0.2 \mathrm{M}, \mathrm{pH} 6.0,18 \mathrm{~mL})$ and laccase $(12 \mathrm{U}, 10 \mathrm{mg}, A$. bisporus) were reacted for $13 \mathrm{~h}$. Workup gave 2-(4,5-dihydroxy2-methylphenylthio)-6-propylpyrimidin-4(3H)-one (5b) as a pale yellow powder $(128 \mathrm{mg}, 88 \%), \mathrm{mp} 189-191{ }^{\circ} \mathrm{C} ; R_{\mathrm{f}}=0.40$ $\left(\mathrm{CH}_{2} \mathrm{Cl}_{2} / \mathrm{EtOAc} / \mathrm{MeOH}=3: 3: 0.1\right) ; \tilde{\nu}_{\max }(\operatorname{atr}) / \mathrm{cm}^{-1} 3439(\mathrm{OH})$, $3179(\mathrm{NH}), 2957(\mathrm{CH}), 1634(\mathrm{C}=\mathrm{O}), 1508(\mathrm{C}=\mathrm{N})$ and 1227; $\delta_{\mathrm{H}}$ (300 MHz; pyridine- $\left.d_{5}\right) 0.75\left(3 \mathrm{H}, \mathrm{t},{ }^{3} J=7.2 \mathrm{~Hz}, 3^{\prime \prime}-\mathrm{H}\right), 1.58(2 \mathrm{H}$, sex like, $\left.{ }^{3} J=7.5 \mathrm{~Hz}, 2^{\prime \prime}-\mathrm{H}\right), 2.39\left(2 \mathrm{H}, \mathrm{t},{ }^{3} J=7.6 \mathrm{~Hz}, 1^{\prime \prime}-\mathrm{H}\right), 2.43$ $\left(3 \mathrm{H}, \mathrm{s}, 2^{\prime}-\mathrm{CH}_{3}\right), 6.31(1 \mathrm{H}, \mathrm{s}, 5-\mathrm{H}), 7.25\left(1 \mathrm{H}, \mathrm{s}, 3^{\prime}-\mathrm{H}\right)$ and 7.67 $\left(1 \mathrm{H}, \mathrm{s}, 6^{\prime}-\mathrm{H}\right) ; \delta_{\mathrm{C}}\left(75 \mathrm{MHz}\right.$; pyridine- $\left.d_{5}\right) 13.64\left(\mathrm{C}-3^{\prime \prime}\right), 20.34\left(2^{\prime}-\right.$ $\left.\mathrm{CH}_{3}\right), 21.44\left(\mathrm{C}-2^{\prime \prime}\right), 39.32\left(\mathrm{C}-1^{\prime \prime}\right), 105.31(\mathrm{C}-5), 116.79\left(\mathrm{C}-1^{\prime}\right)$,
$118.85\left(\mathrm{C}-3^{\prime}\right), 124.96\left(\mathrm{C}^{\prime} 6^{\prime}\right), 135.39\left(\mathrm{C}-2^{\prime}\right), 145.57$ (C-5'), 149.60 $\left(\mathrm{C}-4^{\prime}\right), 166.79(\mathrm{C}-2), 167.68(\mathrm{C}-4)$ and 170.09 (C-6); MS (ESI) $\mathrm{m} / \mathrm{z}$ $331\left([\mathrm{M}+\mathrm{K}]^{+}, 47 \%\right), 315\left([\mathrm{M}+\mathrm{Na}]^{+}, 100\right), 293\left([\mathrm{M}+\mathrm{H}]^{+}, 83\right)$ and 171 (53); HRMS calcd for $\mathrm{C}_{14} \mathrm{H}_{16} \mathrm{~N}_{2} \mathrm{O}_{3} \mathrm{~S}+\mathrm{Na}$ (315.0774), found 315.0767.

Synthesis and analytical data of 2-(4,5-dihydroxy-2-methylphenylthio)-6-isopropylpyrimidin-4(3H)-one (5c).

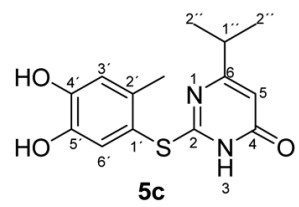

According to general procedure II, 4-methylcatechol (1b) (72 mg, $0.58 \mathrm{mmol}$ ), 2,3-dihydro-6-isopropyl-2-thioxopyrimidin$4(1 \mathrm{H})$-one $(2 \mathrm{~d})(85 \mathrm{mg}, 0.50 \mathrm{mmol})$, ethanol $(2 \mathrm{~mL})$, phosphate buffer $(0.2 \mathrm{M}, \mathrm{pH} 6.0,18 \mathrm{~mL})$ and laccase (12 U, $10 \mathrm{mg}$, A. bisporus) were reacted for $16 \mathrm{~h}$. Workup gave 2-(4,5-dihydroxy-2methylphenylthio)-6-isopropylpyrimidin-4(3H)-one (5c) as a pale yellow powder (134 mg, 92\%), mp 204-206 ${ }^{\circ} \mathrm{C} ; R_{\mathrm{f}}=0.27$ $\left(\mathrm{CH}_{2} \mathrm{Cl}_{2} /\right.$ EtOAc/MeOH $\left.=3: 3: 0.1\right) ; \tilde{\nu}_{\max }(\operatorname{atr}) / \mathrm{cm}^{-1} 3240(\mathrm{OH})$, $2965(\mathrm{CH}), 1644(\mathrm{C}=\mathrm{O}), 1509$ and 1281; $\delta_{\mathrm{H}}(300 \mathrm{MHz}$; pyridine$\left.d_{5}\right) 1.09\left(6 \mathrm{H}, \mathrm{d},{ }^{3} J=6.9 \mathrm{~Hz}, 2^{\prime \prime}-\mathrm{H}\right), 2.42\left(3 \mathrm{H}, \mathrm{s}, 2^{\prime}-\mathrm{CH}_{3}\right), 2.65(1 \mathrm{H}$, sep, $\left.{ }^{3} J=6.9 \mathrm{~Hz}, 1^{\prime \prime}-\mathrm{H}\right), 6.32(1 \mathrm{H}, \mathrm{s}, 5-\mathrm{H}), 7.26\left(1 \mathrm{H}, \mathrm{s}, 3^{\prime}-\mathrm{H}\right)$ and $7.67\left(1 \mathrm{H}, \mathrm{s}, 6^{\prime}-\mathrm{H}\right) ; \delta_{\mathrm{C}}\left(75 \mathrm{MHz}\right.$; pyridine- $\left.d_{5}\right) 20.32\left(2^{\prime}-\mathrm{CH}_{3}\right), 21.20$ $\left(\mathrm{C}-2^{\prime \prime}\right), 35.60\left(\mathrm{C}-1^{\prime \prime}\right), 103.23(\mathrm{C}-5), 116.82\left(\mathrm{C}-1^{\prime}\right), 118.77\left(\mathrm{C}-3^{\prime}\right)$, 124.94 (C-6'), 135.40 (ov., C-2'), 145.51 (C-5'), 149.56 (C-4'), 166.51 (C-2), 167.84 (C-4) and 174.91 (C-6); MS (ESI) $\mathrm{m} / z 315$ ([M $\left.+\mathrm{Na}]^{+}, 100 \%\right), 293\left([\mathrm{M}+\mathrm{H}]^{+}, 44\right)$ and $171(27)$; HRMS calcd for $\mathrm{C}_{14} \mathrm{H}_{16} \mathrm{~N}_{2} \mathrm{O}_{3} \mathrm{~S}+\mathrm{H}$ (293.0954), found 293.0950.

Synthesis and analytical data of 2-(4,5-dihydroxy-2-methylphenylthio)-6-tert-butylpyrimidin-4(3H)-one (5d).<smiles>Cc1cc(O)c(O)cc1Sc1nc(C(F)(F)F)cc(=O)[nH]1</smiles>

According to general procedure II, 4-methylcatechol (1b) (72 mg, $0.58 \mathrm{mmol}$ ), 6-tert-butyl-2,3-dihydro-2-thioxopyrimidin$4(1 H)$-one (2e) (92 mg, $0.50 \mathrm{mmol})$, ethanol ( $2 \mathrm{~mL})$, phosphate buffer $(0.2 \mathrm{M}, \mathrm{pH} 6.0,18 \mathrm{~mL})$ and laccase (12 U, $10 \mathrm{mg}$, A. bisporus) were reacted for $17 \mathrm{~h}$. Workup gave 2-(4,5-dihydroxy-2methylphenylthio)-6-tert-butylpyrimidin-4(3H)-one (5d) as a pale yellow powder (138 mg, 90\%), mp 205-207 ${ }^{\circ} \mathrm{C} ; R_{\mathrm{f}}=0.45$ $\left(\mathrm{CH}_{2} \mathrm{Cl}_{2} /\right.$ EtOAc/MeOH $\left.=3: 3: 0.1\right) ; \tilde{\nu}_{\max }(\operatorname{atr}) / \mathrm{cm}^{-1} 3450(\mathrm{OH})$, $2957(\mathrm{CH}), 1638(\mathrm{C}=\mathrm{O}), 1577(\mathrm{C}=\mathrm{N})$ and 1279; $\delta_{\mathrm{H}}(500 \mathrm{MHz}$; pyridine- $\left.d_{5}\right) 1.14\left(9 \mathrm{H}, \mathrm{s}, 2^{\prime \prime}-\mathrm{H}\right), 2.42\left(3 \mathrm{H}, \mathrm{s}, 2^{\prime}-\mathrm{CH}_{3}\right), 6.43(1 \mathrm{H}, \mathrm{s}, 5-$ $\mathrm{H}), 7.28\left(1 \mathrm{H}, \mathrm{s}, 3^{\prime}-\mathrm{H}\right)$ and $7.66\left(1 \mathrm{H}, \mathrm{s}, 6^{\prime}-\mathrm{H}\right) ; \delta_{\mathrm{C}}(125 \mathrm{MHz}$; pyridine- $\left.d_{5}\right) 20.34\left(2^{\prime}-\mathrm{CH}_{3}\right), 28.73\left(\mathrm{C}-2^{\prime \prime}\right), 37.20\left(\mathrm{C}-1^{\prime \prime}\right), 102.37$ (C-5),

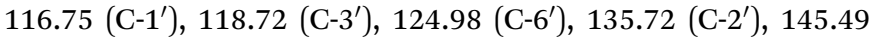
(C-5'), 149.58 (ov., C-4'), 165.32 (C-2), 167.61 (C-4) and 176.73 (C-6); MS (ESI) $m / z 345$ ([M + K $\left.]^{+}, 40 \%\right), 329$ ([M + Na $\left.]^{+}, 100\right), 307$ $\left([\mathrm{M}+\mathrm{H}]^{+}, 77\right), 229$ (24) and 185 (54); HRMS calcd for $\mathrm{C}_{15} \mathrm{H}_{18} \mathrm{~N}_{2} \mathrm{O}_{3} \mathrm{~S}+\mathrm{H}$ (307.1111), found 307.1111. 
Synthesis and analytical data of 2-(4,5-dihydroxy-2-methylphenylthio)-5, 6-dimethylpyrimidin-4(3H)-one (5e).

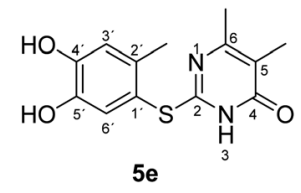

According to general procedure II, 4-methylcatechol (1b) (72 mg, $0.58 \mathrm{mmol}$ ), 2,3-dihydro-5,6-dimethyl-2-thioxopyrimidin$4(1 \mathrm{H})$-one $(2 \mathrm{~g})$ (78 $\mathrm{mg}, 0.50 \mathrm{mmol})$, ethanol $(2 \mathrm{~mL})$, phosphate buffer (0.2 M, pH 6.0, $18 \mathrm{~mL}$ ) and laccase (12 U, $10 \mathrm{mg}$, A. bisporus) were reacted for $20 \mathrm{~h}$. Workup gave 2-(4,5-dihydroxy-2-methylphenylthio)-5,6-dimethylpyrimidin-4(3H)-one (5e) as a pale yellow powder (120 mg, 86\%), mp 229-331 ${ }^{\circ} \mathrm{C} ; R_{\mathrm{f}}=0.45\left(\mathrm{CH}_{2} \mathrm{Cl}_{2} / \mathrm{EtOAc} /\right.$ $\mathrm{MeOH}=3: 3: 0.1) ; \tilde{\nu}_{\max }(\operatorname{atr}) / \mathrm{cm}^{-1} 3420(\mathrm{OH}), 2926(\mathrm{CH}), 1625$ $(\mathrm{C}=\mathrm{O}), 1512$ and $1264 ; \delta_{\mathrm{H}}\left(500 \mathrm{MHz}\right.$; pyridine- $\left.d_{5}\right) 2.06(3 \mathrm{H}, \mathrm{s}, 5-$ $\left.\mathrm{CH}_{3}\right), 2.13\left(3 \mathrm{H}, \mathrm{s}, 6-\mathrm{CH}_{3}\right), 2.46\left(3 \mathrm{H}, \mathrm{s}, 2^{\prime}-\mathrm{CH}_{3}\right), 7.24\left(1 \mathrm{H}, \mathrm{s}, 3^{\prime}-\mathrm{H}\right)$ and $7.69\left(1 \mathrm{H}, \mathrm{s}, 6^{\prime}-\mathrm{H}\right) ; \delta_{\mathrm{C}}\left(125 \mathrm{MHz}\right.$; pyridine- $\left.d_{5}\right) 10.87\left(5-\mathrm{CH}_{3}\right)$, $20.41\left(2^{\prime}-\mathrm{CH}_{3}\right), 21.61\left(6-\mathrm{CH}_{3}\right), 113.56(\mathrm{C}-5), 116.85\left(\mathrm{C}-1^{\prime}\right), 118.92(\mathrm{C}-$ $\left.3^{\prime}\right), 125.00\left(\mathrm{C}-6^{\prime}\right), 135.31\left(\mathrm{C}-2^{\prime}\right), 145.61\left(\mathrm{C}-5^{\prime}\right), 149.60\left(\mathrm{C}-4^{\prime}\right), 161.78$ (C-2), 162.20 (C-6) and 166.32 (C-4); MS (ESI) $m / z 301$ ([M + Na $]^{+}$, 25\%), $279\left([\mathrm{M}+\mathrm{H}]^{+}, 100\right), 263$ (25) and 157 (62); HRMS calcd for $\mathrm{C}_{13} \mathrm{H}_{14} \mathrm{~N}_{2} \mathrm{O}_{3} \mathrm{~S}+\mathrm{H}$ (279.0798), found 279.0797.

Synthesis and analytical data of 2-(2-ethyl-4,5-dihydroxyphenylthio)-6-methylpyrimidin-4(3H)-one (5f).

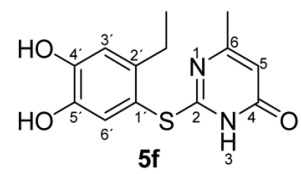

According to general procedure II, 4-ethylcatechol (1c) $(80 \mathrm{mg}$, $0.58 \mathrm{mmol}), \quad 2,3$-dihydro-6-methyl-2-thioxopyrimidin-4(1H)-one (2a) (71 mg, $0.50 \mathrm{mmol})$, ethanol ( $2 \mathrm{~mL})$, phosphate buffer $(0.2 \mathrm{M}$, $\mathrm{pH} 6.0,18 \mathrm{~mL}$ ) and laccase (12 U, $10 \mathrm{mg}, A$. bisporus) were reacted for $14 \mathrm{~h}$. Workup gave 2-(2-ethyl-4,5-dihydroxyphenylthio)-6methylpyrimidin-4(3H)-one (5f) as a pale yellow powder $(125 \mathrm{mg}$, 90\%), mp 180-182 ${ }^{\circ} \mathrm{C} ; R_{\mathrm{f}}=0.31\left(\mathrm{CH}_{2} \mathrm{Cl}_{2} / \mathrm{EtOAc} / \mathrm{MeOH}=\right.$ $3: 3: 0.1) ; \tilde{\nu}_{\max }(\operatorname{atr}) / \mathrm{cm}^{-1} 3400(\mathrm{OH}), 2964(\mathrm{CH}), 1645(\mathrm{C}=\mathrm{O}), 1503$ $(\mathrm{C}=\mathrm{N})$ and $1278 ; \delta_{\mathrm{H}}\left(500 \mathrm{MHz}\right.$; pyridine- $\left.d_{5}\right) 1.17\left(3 \mathrm{H}, \mathrm{t},{ }^{3} J=7.5 \mathrm{~Hz}\right.$, $\left.2^{\prime}-\mathrm{CH}_{2} \mathrm{CH}_{3}\right), 2.13\left(3 \mathrm{H}, \mathrm{s}, 6-\mathrm{CH}_{3}\right), 2.88\left(2 \mathrm{H}, \mathrm{q},{ }^{3} \mathrm{~J}=7.5 \mathrm{~Hz}, 2^{\prime}-\right.$ $\left.\mathrm{CH}_{2} \mathrm{CH}_{3}\right), 6.31(1 \mathrm{H}, \mathrm{s}, 5-\mathrm{H}), 7.27\left(1 \mathrm{H}, \mathrm{s}, 3^{\prime}-\mathrm{H}\right)$ and $7.69\left(1 \mathrm{H}, \mathrm{s}, 6^{\prime}-\mathrm{H}\right)$; $\delta_{\mathrm{C}}\left(125 \mathrm{MHz}\right.$; pyridine- $\left.d_{5}\right) 15.88\left(2^{\prime}-\mathrm{CH}_{2} \mathrm{CH}_{3}\right), 23.64\left(6-\mathrm{CH}_{3}\right), 27.30$ ( $\left.2^{\prime}-\mathrm{CH}_{2} \mathrm{CH}_{3}\right), 105.54(\mathrm{C}-5), 116.11\left(\mathrm{C}-1^{\prime}\right), 117.44\left(\mathrm{C}-3^{\prime}\right), 125.45\left(\mathrm{C}-6^{\prime}\right)$, $141.24\left(\mathrm{C}-2^{\prime}\right), 145.68\left(\mathrm{C}-5^{\prime}\right), 149.92\left(\mathrm{C}-4^{\prime}\right), 166.67$ (C-6), 167.74 (C-2) and $167.93(\mathrm{C}-4)$; MS (ESI) $\mathrm{m} / z 301\left([\mathrm{M}+\mathrm{Na}]^{+}, 100 \%\right), 279\left([\mathrm{M}+\mathrm{H}]^{+}\right.$, 21) and 143 (18); HRMS calcd for $\mathrm{C}_{13} \mathrm{H}_{14} \mathrm{~N}_{2} \mathrm{O}_{3} \mathrm{~S}+\mathrm{H}$ (279.0798), found 279.0790 .

Synthesis and analytical data of 2-(2-ethyl-4,5-dihydroxyphenylthio)-6-isopropylpyrimidin-4(3H)-one (5g).

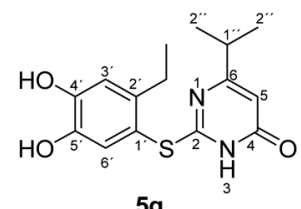

$5 \mathrm{~g}$
According to general procedure II, 4-ethylcatechol (1c) (80 mg, $0.58 \mathrm{mmol}$ ), 2,3-dihydro-6-isopropyl-2-thioxopyrimidin$4(1 \mathrm{H})$-one (2d) (85 mg, $0.50 \mathrm{mmol})$, ethanol $(2 \mathrm{~mL})$, phosphate buffer $(0.2 \mathrm{M}, \mathrm{pH} 6.0,18 \mathrm{~mL})$ and laccase (12 U, $10 \mathrm{mg}$, A. bisporus) were reacted for $12 \mathrm{~h}$. Workup gave 2-(2-ethyl-4,5-dihydroxyphenylthio)-6-isopropylpyrimidin-4(3H)-one (5g) as a pale yellow powder (116 mg, 76\%); mp 158-160 ${ }^{\circ} \mathrm{C} ; R_{\mathrm{f}}=0.50$ $\left(\mathrm{CH}_{2} \mathrm{Cl}_{2} /\right.$ EtOAc/MeOH $\left.=3: 3: 0.1\right) ; \tilde{\nu}_{\max }(\operatorname{atr}) / \mathrm{cm}^{-1} 3323(\mathrm{OH})$, $2962(\mathrm{CH}), 1630(\mathrm{C}=\mathrm{O}), 1514$ and 1252; $\delta_{\mathrm{H}}(300 \mathrm{MHz}$; pyridine$\left.d_{5}\right) 1.09\left(6 \mathrm{H}, \mathrm{d},{ }^{3} J=7.0 \mathrm{~Hz}, 2^{\prime \prime}-\mathrm{H}\right), 1.16\left(3 \mathrm{H}, \mathrm{t},{ }^{3} J=7.5 \mathrm{~Hz}, 2^{\prime}-\right.$ $\left.\mathrm{CH}_{2} \mathrm{CH}_{3}\right), 2.66\left(1 \mathrm{H}\right.$, sep, $\left.{ }^{3} J=7.0 \mathrm{~Hz}, 1^{\prime \prime}-\mathrm{H}\right), 2.86\left(2 \mathrm{H}, \mathrm{q},{ }^{3} J=\right.$ $\left.7.5 \mathrm{~Hz}, 2^{\prime}-\mathrm{CH}_{2} \mathrm{CH}_{3}\right), 6.32(1 \mathrm{H}, \mathrm{s}, 5-\mathrm{H}), 7.28\left(1 \mathrm{H}, \mathrm{s}, 3^{\prime}-\mathrm{H}\right)$ and 7.67 $\left(1 \mathrm{H}, \mathrm{s}, 6^{\prime}-\mathrm{H}\right) ; \delta_{\mathrm{C}}\left(75 \mathrm{MHz}\right.$; pyridine- $\left.d_{5}\right) 15.80\left(2^{\prime}-\mathrm{CH}_{2} \mathrm{CH}_{3}\right), 21.25$ $\left(\mathrm{C}-2^{\prime \prime}\right), 27.24\left(2^{\prime}-\mathrm{CH}_{2} \mathrm{CH}_{3}\right), 35.63\left(\mathrm{C}-1^{\prime \prime}\right), 103.06(\mathrm{C}-5), 116.20(\mathrm{C}-$ $\left.1^{\prime}\right), 117.29\left(\mathrm{C}-3^{\prime}\right), 125.44\left(\mathrm{C}-6^{\prime}\right), 141.26\left(\mathrm{C}-2^{\prime}\right), 145.57\left(\mathrm{C}-5^{\prime}\right)$, 150.20 (ov., C-4'), 167.33 (C-2), 168.02 (C-4) and 175.01 (C-6); MS (ESI) $m / z 345\left([\mathrm{M}+\mathrm{K}]^{+}, 23 \%\right), 329\left([\mathrm{M}+\mathrm{Na}]^{+}, 100\right), 307\left([\mathrm{M}+\mathrm{H}]^{+}\right.$, 21) and 215 (14); HRMS calcd for $\mathrm{C}_{15} \mathrm{H}_{18} \mathrm{~N}_{2} \mathrm{O}_{3} \mathrm{~S}+\mathrm{H}$ (307.1111), found 307.1103 .

Synthesis and analytical data of 2-(2-ethyl-4,5-dihydroxyphenylthio)-6-tert-butylpyrimidin-4(3H)-one (5h).<smiles>CCc1cc(O)c(O)cc1Sc1nc(C(C)(C)C)cc(=O)[nH]1</smiles>

According to general procedure II, 4-ethylcatechol (1c) $(80 \mathrm{mg}$, $0.58 \mathrm{mmol})$, 6-tert-butyl-2,3-dihydro-2-thioxopyrimidin-4(1H)-one (2e) (92 mg, $0.50 \mathrm{mmol}$ ), ethanol (2 mL), phosphate buffer (0.2 M, $\mathrm{pH} 6.0,18 \mathrm{~mL}$ ) and laccase (12 U, $10 \mathrm{mg}, A$. bisporus) were reacted for $16 \mathrm{~h}$. Workup gave 2-(2-ethyl-4,5-dihydroxyphenylthio)-6-tertbutylpyrimidin-4(3H)-one $(\mathbf{5 h})$ as a pale yellow powder $(130 \mathrm{mg}$, 81\%), mp 153-155 ${ }^{\circ} \mathrm{C} ; R_{\mathrm{f}}=0.49\left(\mathrm{CH}_{2} \mathrm{Cl}_{2} / \mathrm{EtOAc} / \mathrm{MeOH}=\right.$ $3: 3: 0.1) ; \tilde{\nu}_{\max }(\operatorname{atr}) / \mathrm{cm}^{-1} 3410(\mathrm{OH}), 2962(\mathrm{CH}), 1632(\mathrm{C}=\mathrm{O})$, $1512(\mathrm{C}=\mathrm{N})$ and $1275 ; \delta_{\mathrm{H}}\left(300 \mathrm{MHz}\right.$; pyridine- $\left.d_{5}\right) 1.15\left(9 \mathrm{H}, \mathrm{s}, 2^{\prime \prime}-\right.$ $\mathrm{H}), 1.17\left(3 \mathrm{H}, \mathrm{t},{ }^{3} J=7.5 \mathrm{~Hz}, 2^{\prime}-\mathrm{CH}_{2} \mathrm{CH}_{3}\right), 2.84\left(2 \mathrm{H}, \mathrm{q},{ }^{3} J=7.4 \mathrm{~Hz}, 2^{\prime}-\right.$ $\left.\mathrm{CH}_{2} \mathrm{CH}_{3}\right), 6.44(1 \mathrm{H}, \mathrm{s}, 5-\mathrm{H}), 7.30\left(1 \mathrm{H}, \mathrm{s}, 3^{\prime}-\mathrm{H}\right)$ and $7.67\left(1 \mathrm{H}, \mathrm{s}, 6^{\prime}-\mathrm{H}\right)$; $\delta_{\mathrm{C}}\left(75 \mathrm{MHz}\right.$; pyridine- $\left.d_{5}\right) 15.79\left(2^{\prime}-\mathrm{CH}_{2} \underline{\mathrm{CH}_{3}}\right), 27.24\left(2^{\prime}-\mathrm{CH}_{2} \mathrm{CH}_{3}\right)$, $28.75\left({\mathrm{C}-2^{\prime \prime}}^{\prime \prime}, 37.19\left(\mathrm{C}-1^{\prime \prime}\right), 102.12(\mathrm{C}-5), 116.14\left(\mathrm{C}-1^{\prime}\right), 117.20\left(\mathrm{C}-3^{\prime}\right)\right.$, 125.47 (C-6'), 141.28 (C-2'), 145.52 (C-5'), 149.8 (ov., C-4'), 166.20 (C-2 or C-4), 167.80 (C-2 or C-4) and 176.82 (C-6); MS (ESI) m/z 343 $\left([\mathrm{M}+\mathrm{Na}]^{+}, 100 \%\right), 321\left([\mathrm{M}+\mathrm{H}]^{+}, 38\right)$ and 185 (25); HRMS calcd for $\mathrm{C}_{16} \mathrm{H}_{20} \mathrm{~N}_{2} \mathrm{O}_{3} \mathrm{~S}+\mathrm{H}$ (321.1267), found 321.1260.

Synthesis and analytical data of 2-(2-ethyl-4,5-dihydroxyphenylthio)-5, 6-dimethylpyrimidin-4(3H)-one (5i).

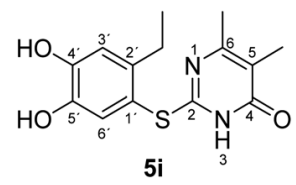

According to general procedure II, 4-ethylcatechol (1c) (80 mg, $0.58 \mathrm{mmol}$ ), 2,3-dihydro-5,6-dimethyl-2-thioxopyrimidin-4(1H)-one (2g) (78 mg, $0.50 \mathrm{mmol})$, ethanol $(2 \mathrm{~mL})$, phosphate buffer $(0.2 \mathrm{M}, \mathrm{pH} 6.0,18 \mathrm{~mL})$ and laccase (12 U, 
$10 \mathrm{mg}$, A. bisporus) were reacted for $16 \mathrm{~h}$. Workup gave 2-(2ethyl-4,5-dihydroxyphenylthio)-5,6-dimethylpyrimidin-4(3H)-one (5i) as a pale yellow powder (133 mg, 91\%), mp $185-187^{\circ} \mathrm{C} ; R_{\mathrm{f}}=$ $0.43\left(\mathrm{CH}_{2} \mathrm{Cl}_{2} / \mathrm{EtOAc} / \mathrm{MeOH}=3: 3: 0.1\right) ; \tilde{\nu}_{\max }($ atr $) / \mathrm{cm}^{-1} 3403$ $(\mathrm{OH}), 2927(\mathrm{CH}), 1629(\mathrm{C}=\mathrm{O}), 1523(\mathrm{C}=\mathrm{N})$ and 1252; $\delta_{\mathrm{H}}(500$ MHz; pyridine- $\left.d_{5}\right) 1.19\left(3 \mathrm{H}, \mathrm{t},{ }^{3} \mathrm{~J}=7.5 \mathrm{~Hz}, 2^{\prime}-\mathrm{CH}_{2} \mathrm{CH}_{3}\right), 2.06$ $\left(3 \mathrm{H}, \mathrm{s}, 5-\mathrm{CH}_{3}\right), 2.13\left(3 \mathrm{H}, \mathrm{s}, 6-\mathrm{CH}_{3}\right), 2.88\left(2 \mathrm{H}, \mathrm{q},{ }^{3} J=7.5 \mathrm{~Hz}, 2^{\prime}-\right.$ $\left.\mathrm{C}_{2} \mathrm{CH}_{3}\right), 7.27\left(1 \mathrm{H}, \mathrm{s}, 3^{\prime}-\mathrm{H}\right)$ and $7.70\left(1 \mathrm{H}, \mathrm{s}, 6^{\prime}-\mathrm{H}\right) ; \delta_{\mathrm{C}}(125 \mathrm{MHz}$; pyridine- $\left.d_{5}\right) 10.82\left(5-\mathrm{CH}_{3}\right), 15.86\left(2^{\prime}-\mathrm{CH}_{2} \underline{\mathrm{CH}_{3}}\right), 21.55\left(6-\mathrm{CH}_{3}\right)$, $27.27\left(2^{\prime}-\mathrm{CH}_{2} \mathrm{CH}_{3}\right), 113.42(\mathrm{C}-5), 116.19\left(\mathrm{C}-1^{\prime}\right), 117.38\left(\mathrm{C}-3^{\prime}\right)$, $125.40\left({\mathrm{C}-6^{\prime}}^{\prime}\right), 141.15\left(\mathrm{C}-2^{\prime}\right), 145.64\left(\mathrm{C}-5^{\prime}\right), 149.80$ (ov., C-4' $), 162.20$ (C-6), 162.43 (C-2) and 166.34 (C-4); MS (ESI) $m / z 315\left([\mathrm{M}+\mathrm{Na}]^{+}\right.$, $100 \%), 293\left([\mathrm{M}+\mathrm{H}]^{+}, 69\right)$ and 157 (41); HRMS calcd for $\mathrm{C}_{14} \mathrm{H}_{16} \mathrm{~N}_{2} \mathrm{O}_{3} \mathrm{~S}+\mathrm{H}$ (293.0954), found 293.0949.

Synthesis and analytical data of 2-(4,5-dihydroxy-2-methylphenylthio)-6, 7-dihydro-3H-cyclopenta[d]pyrimidin-4(5H)-one (5j).

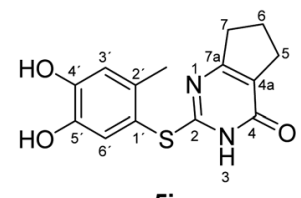

5j

According to general procedure II, 4-methylcatechol (1b) (72 mg, $0.58 \mathrm{mmol}$ ), 2,3,6,7-tetrahydro-2-thioxo- $1 H$-cyclopenta[d] pyrimidin-4(5H)-one $(2 \mathrm{i})(84 \mathrm{mg}, 0.50 \mathrm{mmol})$, ethanol $(2 \mathrm{~mL})$, phosphate buffer $(0.2 \mathrm{M}, \mathrm{pH} 6.0,18 \mathrm{~mL})$ and laccase (12 U, $10 \mathrm{mg}$, A. bisporus) were reacted for $14 \mathrm{~h}$. Workup gave 2-(4,5-dihydroxy-2methylphenylthio)-6,7-dihydro-3H-cyclopenta[ $d]$ pyrimidin-4(5H)one (5j) as a pale yellow powder $(130 \mathrm{mg}, 90 \%), \mathrm{mp} 240-242{ }^{\circ} \mathrm{C} ; R_{\mathrm{f}}$ $=0.30\left(\mathrm{CH}_{2} \mathrm{Cl}_{2} / \mathrm{EtOAc} / \mathrm{MeOH}=3: 3: 0.1\right) ; \tilde{\nu}_{\max }($ atr $) / \mathrm{cm}^{-1} 3480$ $(\mathrm{OH}), 2924(\mathrm{CH}), 1639(\mathrm{C}=\mathrm{O}), 1512$ and 1278; $\delta_{\mathrm{H}}(500 \mathrm{MHz}$; pyridine- $\left.d_{5}\right) 1.72(2 \mathrm{H}$, quin, 6- $\mathrm{H}), 2.47\left(3 \mathrm{H}, \mathrm{s}, 2^{\prime}-\mathrm{CH}_{3}\right), 2.57(2 \mathrm{H}, \mathrm{t}$, $\left.{ }^{3} J=7.7 \mathrm{~Hz}, 7-\mathrm{H}\right), 2.75\left(2 \mathrm{H}, \mathrm{t},{ }^{3} J=7.7 \mathrm{~Hz}, 5-\mathrm{H}\right), 7.21\left(1 \mathrm{H}, \mathrm{s}, 3^{\prime}-\mathrm{H}\right)$ and $7.70\left(1 \mathrm{H}, \mathrm{s}, 6^{\prime}-\mathrm{H}\right) ; \delta_{\mathrm{C}}\left(125 \mathrm{MHz}\right.$; pyridine- $\left.d_{5}\right) 20.42\left(2^{\prime}-\mathrm{CH}_{3}\right)$, 21.37 (C-6), 27.41 (C-5), 34.89 (C-7), $115.94\left(\mathrm{C}-1^{\prime}\right), 118.93\left(\mathrm{C}-3^{\prime}\right)$, 119.48 (C-4a), 125.03 (C-6'), 135.35 (ov., C-2'), 145.71 (C-5'), 149.80 (ov., C-4'), 163.05 (C-4), 163.32 (C-2) and 171.02 (C-7a); MS (ESI) $m / z 313\left([\mathrm{M}+\mathrm{Na}]^{+}, 93 \%\right), 291\left([\mathrm{M}+\mathrm{H}]^{+}, 100\right)$ and $169(67)$; HRMS calcd for $\mathrm{C}_{14} \mathrm{H}_{14} \mathrm{~N}_{2} \mathrm{O}_{3} \mathrm{~S}+\mathrm{H}$ (291.0798), found 291.0788.

Synthesis and analytical data of 2-(2-ethyl-4,5-dihydroxyphenylthio)-6,7-dihydro-3H-cyclopenta[d]pyrimidin-4(5H)-one (5k).

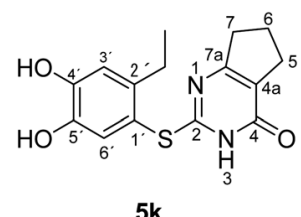

According to general procedure II, 4-ethylcatechol (1c) $(80 \mathrm{mg}$, $0.58 \mathrm{mmol}), \quad 2,3,6,7$-tetrahydro-2-thioxo- $1 H$-cyclopenta $[d]$ pyrimidin-4(5H)-one (2i) (84 mg, $0.50 \mathrm{mmol})$, ethanol ( $2 \mathrm{~mL})$, phosphate buffer $(0.2 \mathrm{M}, \mathrm{pH} 6.0,18 \mathrm{~mL})$ and laccase $(12 \mathrm{U}, 10 \mathrm{mg}, A$. bisporus) were reacted for $14 \mathrm{~h}$. Workup gave 2-(2-ethyl-4,5-dihydroxyphenylthio)-6,7-dihydro-3 $H$-cyclopenta[d]pyrimidin-4 $(5 H)$ one (5k) as a pale yellow powder $(115 \mathrm{mg}, 76 \%)$, mp $178-180{ }^{\circ} \mathrm{C}$; $R_{\mathrm{f}}=0.36\left(\mathrm{CH}_{2} \mathrm{Cl}_{2} / \mathrm{EtOAc} / \mathrm{MeOH}=3: 3: 0.1\right) ; \tilde{\nu}_{\max }(\mathrm{atr}) / \mathrm{cm}^{-1}$
$3500(\mathrm{OH}), 2962(\mathrm{CH}), 1639(\mathrm{C}=\mathrm{O}), 1534(\mathrm{C}=\mathrm{N})$ and 1285; $\delta_{\mathrm{H}}$ (500 MHz; pyridine- $\left.d_{5}\right) 1.20\left(3 \mathrm{H}, \mathrm{t},{ }^{3} J=7.6 \mathrm{~Hz}, 2^{\prime}-\mathrm{CH}_{2} \mathrm{CH}_{3}\right), 1.72$ (2H, quin, $\left.{ }^{3} J=7.5 \mathrm{~Hz}, 6-\mathrm{H}\right), 2.56\left(2 \mathrm{H}, \mathrm{t},{ }^{3} J=7.5 \mathrm{~Hz}, 7-\mathrm{H}\right), 2.75$ $\left(2 \mathrm{H}, \mathrm{t},{ }^{3} \mathrm{~J}=7.5 \mathrm{~Hz}, 5-\mathrm{H}\right), 2.88\left(2 \mathrm{H}, \mathrm{q},{ }^{3} J=7.6 \mathrm{~Hz}, 2^{\prime}-\mathrm{CH}_{2} \mathrm{CH}_{3}\right)$, $7.24\left(1 \mathrm{H}, \mathrm{s}, 3^{\prime}-\mathrm{H}\right)$ and $7.72\left(1 \mathrm{H}, \mathrm{s}, 6^{\prime}-\mathrm{H}\right) ; \delta_{\mathrm{C}}(125 \mathrm{MHz}$; pyridine$\left.d_{5}\right) 15.89\left(2^{\prime}-\mathrm{CH}_{2} \mathrm{CH}_{3}\right), 21.36(\mathrm{C}-6), 27.30\left(2^{\prime}-\mathrm{CH}_{2} \mathrm{CH}_{3}\right), 27.40(\mathrm{C}-$ 5), 34.85 (C-7), $115.21\left(\mathrm{C}-1^{\prime}\right), 117.41$ (C-3'), 119.48 (C-4a), 125.41

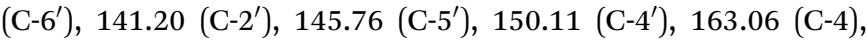
163.85 (C-2) and 171.04 (C-7a); MS (ESI) $m / z 327\left([\mathrm{M}+\mathrm{Na}]^{+}\right.$, $100 \%), 305\left([\mathrm{M}+\mathrm{H}]^{+}, 41\right)$ and 169 (14); HRMS calcd for $\mathrm{C}_{15} \mathrm{H}_{16} \mathrm{~N}_{2} \mathrm{O}_{3} \mathrm{~S}+\mathrm{H}$ (305.0954), found 305.0946.

\section{Biology}

Sulforhodamine assay. The human HepG2 cell line (kindly provided by Prof. Dr Lutz Graeve; Institut für Biologische Chemie und Ernährungswissenschaft, Universität Hohenheim) was grown in DMEM/Hams's medium (Merck) containing 10\% fetal bovine serum (Merck) and 1\% penicillin/streptomycin. Cells were inoculated into 96 well microtiter plates (Sarstedt) in $100 \mu \mathrm{L}$ at plating densities $\sim 5000$ cells per well. After cell inoculation, the microtiter plates were incubated at $37{ }^{\circ} \mathrm{C}, 5 \% \mathrm{CO}_{2}, 95 \%$ air and $100 \%$ relative humidity for $24 \mathrm{~h}$ prior to addition of compounds under test or doxorubicin (Sigma, cat. no. D2975000). Experimental drugs were prepared as $4 \mathrm{mM}$ solution in DMSO and stored frozen prior to use. At the time of drug addition, an aliquot of frozen concentrate and pure DMSO were thawed and diluted with complete DMEM/Hams's medium containing 10\% fetal bovine serum and $1 \%$ penicillin/streptomycin. An aliquot of $100 \mu \mathrm{L}$ of $4 \%$ DMSO was added to the microtiter wells containing $100 \mu \mathrm{L}$ of medium. An aliquot of $100 \mu \mathrm{L}$ of the drug dilution was added to the appropriate microtiter wells, resulting in the required final drug concentrations $(2.5-80 \mu \mathrm{M})$. Six wells were prepared for each individual dose. Following drug addition, the plates were incubated for an additional $48 \mathrm{~h}$ at $37{ }^{\circ} \mathrm{C}, 5 \% \mathrm{CO}_{2}, 95 \%$ air, and $100 \%$ relative humidity. The assay was terminated by the addition of cold trichloroacetic acid (TCA). Cells were fixed in situ by gentle addition of $50 \mu \mathrm{L}$ of cold $50 \%$ (w/v) TCA (final concentration, 10\% TCA) and incubated for $60 \mathrm{~min}$ at $4{ }^{\circ} \mathrm{C}$. The supernatant was discarded, and the plates were washed five times with tap water and air dried. Sulforhodamine B (SRB) (Sigma-Aldrich, cat. no. S1402) solution $(100 \mu \mathrm{L})$ at $0.4 \%(\mathrm{w} / \mathrm{v})$ in $1 \%$ acetic acid was added to each well, and plates were incubated for $10 \mathrm{~min}$ at room temperature. After staining, unbound dye was removed by washing at least five times with $1 \%$ acetic acid and the plates were dried. Bound stain was subsequently solubilized with $10 \mathrm{mM}$ Trizma base $\mathrm{pH} 10.5$, and the absorbance was read on ELISA microplate reader at a wavelength of $515 \mathrm{~nm}$. $\mathrm{IC}_{50}$ was calculated for each experiment using four parameter logistic equation (Graph Pad, Prism Version 5). $\mathrm{IC}_{50}$ results represent the mean of 2-5 experiments with the standard error of the mean indicating the variation.

\section{Conclusions}

To summarize, simple-to-perform, efficient and sustainable methods for the synthesis of regioisomeric pyrimidobenzothiazoles 3, $\mathbf{4}$ as well as catechol thioethers 5 by laccase-catalyzed 
domino reactions between catechols 1 and 2,3-dihydro-2-thioxopyrimidin-4-( $1 H)$-ones 2 have been developed. The transformations rely on the laccase-catalyzed oxidation of a catechol 1 to the corresponding $o$-benzoquinone $\mathbf{8}$ which in turn undergoes reaction with a 2,3-dihydro-2-thioxopyrimidin-4(1H)-one 2 . Depending on the substitution pattern of the 2,3-dihydro-2-thioxopyrimidin-4(1H)-one 2 , the laccase-catalyzed reactions with unsubstituted catechol (1a) deliver either 7,8-dihydroxy-4H-pyrimido[2,1- $b]$ benzothiazol-4-ones 3 and/or 7,8-dihydroxy-2H-pyrimido[2,1- $b]$ benzothiazol-2-ones 4. With 4-substituted catechols $\mathbf{1 b}$, c, catechol thioethers 5 are formed exclusively. All reactions can be performed under mild reaction conditions with aerial $\mathrm{O}_{2}$ as the oxidant, and the products are formed with yields ranging between 76 and $97 \%$. In addition, the cytotoxicity of selected pyrimidobenzothiazoles $\mathbf{3}$ and catechol thioethers 5 against HepG2 cell line is reported. A structure-activity relationship study reveals that the most potent compounds are $\mathbf{5 c}\left(\mathrm{IC}_{50}=7.77\right.$ $\mu \mathrm{M})$ and $5 \mathrm{~g}\left(\mathrm{IC}_{50}=2.74 \mu \mathrm{M}\right)$ which carry an isopropyl group at C6. The presence of an additional ethyl group at $\mathrm{C}-2^{\prime}$ of $5 \mathbf{g}$ increases the cytotoxic potency in comparison to $\mathbf{5 c}$.

\section{Acknowledgements}

We thank Mr M. Wolf (Institut für Chemie, Universität Hohenheim) for recording NMR spectra as well as Dipl.-Ing. (FH) J. Trinkner and D. Garnier (Institut für Organische Chemie, Universität Stuttgart) for recording mass spectra. Special thanks to Prof. Dr Lutz Graeve; (Institut für Biologische Chemie und Ernährungswissenschaft, Universität Hohenheim) for providing the HepG2 cell line. We acknowledge the help of A. Flaccus and D. Mvondo (Institut für Biologische Chemie und Ernährungswissenschaft, Universität Hohenheim) in carrying out the SRB assay. H. T. A.-M. is grateful to Science Technology Development Fund (STDF) for financial support (Project ID 11978).

\section{Notes and references}

1 (a) V. Sharma, N. Chitranshi and A. K. Agarwal, Int. J. Med. Chem., 2014, 202784; (b) K. S. Jain, T. S. Chitre, P. B. Miniyar, M. K. Kathiravan, V. S. Bendre, V. S. Veer, S. R. Shahana and C. J. Shishoo, Curr. Sci., 2006, 90, 793.

2 A. Kleemann, J. Engel, B. Kutscher and D. Reichert, Pharmaceutical Substances, Thieme, Stuttgart, 5th edn, 2000.

3 (a) E. Sherman, in Lippincott Illustrated Reviews: Pharmacology, ed. K. Whalen, Wolters Kluwer, Philadelphia, 6th edn, 2015, ch. 45, p. 567; (b) K. LaPlant and P. Louzon, in Lippincott Illustrated Reviews: Pharmacology, ed. K. Whalen, Wolters Kluwer, Philadelphia, 6th edn, 2015, ch. 46, p. 587; (c) R. Kaur, P. Kaur, S. Sharma, G. Singh, S. Mehndiratta, P. M. S. Bedi and K. Nepali, Recent Pat. Anti-Cancer Drug Discovery, 2015, 10, 23.

4 (a) R. Bandichhor, A. Bhattacharya, M. C. Bryan, A. Cosbie, A. Díaz-Rodríguez, L. Diorazio, Z. Fei, K. Fraunhoffer, J. Hayler, M. Hickey, L. Humphreys, P. Richardson, S. Roberts, T. White, S. Wuyts and J. Yin, Org. Process Res.
Dev., 2016, 20, 1118; (b) F. Roschangar, R. A. Sheldon and C. H. Senanayake, Green Chem., 2015, 17, 752; (c) E. A. Peterson and J. B. Manley, Green Chemistry Strategies for Drug Discovery, in RSC Drug Discovery Series, Royal Society of Chemistry, Thomas Graham House, Cambridge, 2015; (d) P. Gupta and A. Mahajan, RSC Adv., 2015, 5, 26686; (e) H.-J. Federsel, Green Chem., 2013, 15, 3105.

5 B. M. Trost, Angew. Chem., Int. Ed., 1995, 34, 259.

6 (a) R. A. Sheldon, I. W. C. E. Arends and U. Hanefeld, Green Chemistry and Catalysis, WILEY-VCH, Weinheim, 2007; (b) P. T. Anastas and J. C. Warner, Green Chemistry Theory and Practice, Oxford University Press, New York, 2000; (c) K. Alfonsi, J. Colberg, P. J. Dunn, T. Fevig, S. Jennings, T. A. Johnson, H. P. Kleine, C. Knight, M. A. Nagy, D. A. Perry and M. Stefaniak, Green Chem., 2008, 10, 31; (d) D. J. C. Constable, P. J. Dunn, J. D. Hayler, G. R. Humphrey, J. L. Leazer Jr, R. J. Linderman, K. Lorenz, J. Manley, B. A. Pearlman, A. S. Wells, A. Zaks and T. Y. Zhang, Green Chem., 2007, 9, 411.

7 (a) R. Dhanasekaran, A. Limaye and R. Cabrera, Hepatic Med., 2012, 4, 19; (b) S. Mittal and H. B. El-Serag, J. Clin. Gastroenterol., 2013, 47, S2; (c) E. Carr and J. A. Killman, Basics of Cancer Chemotherapy (Clinical Nursing Series), Western Schools Press, Canada, 3rd edn, 1995.

8 (a) S.-I. Shoda, H. Uyama, J.-I. Kadokawa, S. Kimura and S. Kobayashi, Chem. Rev., 2016, 116, 2307; (b) D. Monti, G. Ottolina, G. Carrea and S. Riva, Chem. Rev., 2011, 111, 4111; (c) F. Hollmann, I. W. C. E. Arends, K. Buehler, A. Schallmey and B. Bühler, Green Chem., 2011, 13, 226.

9 (a) O. V. Morozova, G. P. Shumakovich, M. A. Gorbacheva, S. V. Shleev and A. I. Yaropolov, Biochemistry (Moscow), 2007, 72, 1136; (b) H. Claus, Micron, 2004, 35, 93; (c) A. M. Mayer and R. C. Staples, Phytochemistry, 2002, 60, 551; (d) C. F. Thurston, Microbiology, 1994, 140, 19.

10 (a) S. Witayakran and A. J. Ragauskas, Adv. Synth. Catal., 2009, 351, 1187; (b) A. Mikolasch and F. Schauer, Appl. Microbiol. Biotechnol., 2009, 82, 605; (c) A. Kunamneni, S. Camarero, C. García-Burgos, F. J. Plou, A. Ballesteros and M. Alcalde, Microb. Cell Fact., 2008, 7, 32.

11 (a) J. González-Sabín, N. Ríos-Lombardía, I. García, N. M. Vior, A. F. Braña, C. Méndez, J. A. Salas and F. Morís, Green Chem., 2016, 18, 989; (b) K. Kędziora, A. Díaz-Rodríguez, I. Lavandera, V. Gotor-Fernández and V. Gotor, Green Chem., 2014, 16, 2448; (c) H. T. AbdelMohsen, K. Sudheendran, J. Conrad and U. Beifuss, Green Chem., 2013, 15, 1490; (d) H. T. Abdel-Mohsen, J. Conrad and U. Beifuss, Green Chem., 2012, 14, 2686; (e) H. Leutbecher, M.-A. Constantin, S. Mika, J. Conrad and U. Beifuss, Tetrahedron Lett., 2011, 52, 604; $(f)$ A. Coniglio, C. Galli, P. Gentili and R. Vadalà, J. Mol. Catal. B: Enzym., 2008, 50, 40; (g) F. d'Acunzo, P. Baiocco and C. Galli, New J. Chem., 2003, 27, 329; (h) M. Fabbrini, C. Galli, P. Gentili and D. Macchitella, Tetrahedron Lett., 2001, 42, 7551; (i) A. Potthast, T. Rosenau, C.-L. Chen and J. S. Gratzl, J. Org. Chem., 1995, 60, 4320.

12 (a) A. Llevot, E. Grau, S. Carlotti, S. Grelier and H. Cramail, J. Mol. Catal. B: Enzym., 2016, 125, 34; (b) C. Engelmann, 
S. Illner and U. Kragl, Process Biochem., 2015, 50, 1591; (c) M.-A. Constantin, J. Conrad and U. Beifuss, Green Chem., 2012, 14, 2375; (d) M.-A. Constantin, J. Conrad, E. Merişor, K. Koschorreck, V. B. Urlacher and U. Beifuss, J. Org. Chem., 2012, 77, 4528; (e) B. Pickel, M.-A. Constantin, J. Pfannstiel, J. Conrad, U. Beifuss and A. Schaller, Angew. Chem., Int. Ed., 2010, 49, 202; (f) S. Ncanana, L. Baratto, L. Roncaglia, S. Riva and S. G. Burton, Adv. Synth. Catal., 2007, 349, 1507; (g) C. Ponzoni, E. Beneventi, M. R. Cramarossa, S. Raimondi, G. Trevisi, U. M. Pagnoni, S. Riva and L. Forti, Adv. Synth. Catal., 2007, 349, 1497; (h) S. Ciecholewski, E. Hammer, K. Manda, G. Bose, V. T. H. Nguyen, P. Langer and F. Schauer, Tetrahedron, 2005, 61, 4615.

13 (a) S. Emirdağ-Öztürk, S. Hajdok, J. Conrad and U. Beifuss, Tetrahedron, 2013, 69, 3664; (b) J. Pietruszka and C. Wang, Green Chem., 2012, 14, 2402; (c) J. Pietruszka and C. Wang, ChemCatChem, 2012, 4, 782; (d) S. Hajdok, J. Conrad and U. Beifuss, J. Org. Chem., 2012, 77, 445.

14 (a) V. Hahn, A. Mikolasch, C. Kuhlisch and F. Schauer, J. Mol. Catal. B: Enzym., 2015, 122, 56; (b) S. Herter, D. Michalik, A. Mikolasch, M. Schmidt, R. Wohlgemuth, U. Bornscheuer and F. Schauer, J. Mol. Catal. B: Enzym., 2013, 90, 91; (c) K. W. Wellington and N. I. Kolesnikova, Bioorg. Med. Chem., 2012, 20, 4472; (d) S. Herter, A. Mikolasch, D. Michalik, E. Hammer, F. Schauer, U. Bornscheuer and M. Schmidt, Tetrahedron, 2011, 67, 9311; (e) V. Hahn, T. Davids, M. Lalk, F. Schauer and A. Mikolasch, Green Chem., 2010, 12, 879; $(f)$ A. Mikolasch, A. Matthies, M. Lalk and F. Schauer, Appl. Microbiol. Biotechnol., 2008, 80, 389.

15 (a) M. Schlippert, A. Mikolasch, V. Hahn and F. Schauer, J. Mol. Catal. B: Enzym., 2016, 126, 106; (b) H. T. AbdelMohsen, J. Conrad and U. Beifuss, Green Chem., 2014, 16, 90; (c) K. W. Wellington, G. E. R. Gordon, L. A. Ndlovu and P. Steenkamp, ChemCatChem, 2013, 5, 1570; (d) K. W. Wellington, R. Bokako, N. Raseroka and P. Steenkamp, Green Chem., 2012, 14, 2567.

16 (a) A. C. Sousa, M. F. M. M. Piedade, L. O. Martins and M. P. Robalo, Green Chem., 2015, 17, 1429; (b) M. D. Cannatelli and A. J. Ragauskas, J. Mol. Catal. B: Enzym., 2015, 119, 85; (c) A. C. Sousa, M. C. Oliveira, L. O. Martins and M. P. Robalo, Green Chem., 2014, 16, 4127; (d) H. T. Abdel-Mohsen, J. Conrad and U. Beifuss, $J$. Org. Chem., 2013, 78, 7986; (e) K. W. Wellington, G. E. R. Gordon, L. A. Ndlovu and P. Steenkamp,
ChemCatChem, 2013, 5, 1570; ( $f$ ) M. Kidwai, A. Jain, A. Sharma and R. C. Kuhad, Catal. Sci. Technol., 2013, 3, 230; $(g)$ H. Leutbecher, G. Greiner, R. Amann, A. Stolz, U. Beifuss and J. Conrad, Org. Biomol. Chem., 2011, 9, 2667; (h) S. Hajdok, J. Conrad, H. Leutbecher, S. Strobel, T. Schleid and U. Beifuss, J. Org. Chem., 2009, 74, 7230; (i) H. Leutbecher, S. Hajdok, C. Braunberger, M. Neumann, S. Mika, J. Conrad and U. Beifuss, Green Chem., 2009, 11, 676; (j) S. Witayakran, L. Gelbaum and A. J. Ragauskas, Tetrahedron, 2007, 63, 10958; ( $k$ ) S. Hajdok, H. Leutbecher, G. Greiner, J. Conrad and U. Beifuss, Tetrahedron Lett., 2007, 48, 5073; (l) S. Witayakran, A. Zettili and A. J. Ragauskas, Tetrahedron Lett., 2007, 48, 2983; (m) S. Witayakran and A. J. Ragauskas, Green Chem., 2007, 9, 475; $(n)$ H. Leutbecher, J. Conrad, I. Klaiber and U. Beifuss, Synlett, 2005, 3126.

17 (a) M. Barmaki, G. Valiyeva, A. A. Maharramovm and M. M. Allaverdiyev, J. Chem., 2013, 176213; (b) K.-P. Shao, X.-Y. Zhang, P.-J. Chen, D.-Q. Xue, P. He, L.-Y. Ma, J.-X. Zheng, Q.-R. Zhang and H.-M. Liu, Bioorg. Med. Chem. Lett., 2014, 24, 2741.

18 S. Nicotra, A. Intra, G. Ottolina, S. Riva and B. Danieli, Tetrahedron: Asymmetry, 2004, 15, 2927.

19 Structure solution and refinement using programs SHELXT and SHELXL (a) G. M. Sheldrick, Acta Crystallogr., Sect. A: Found. Adv., 2015, 71, 3; (b) G. M. Sheldrick, Acta Crystallogr., Sect. C: Struct. Chem., 2015, 71, 3. CCDC 1514742 (3f) and 1514743 (5a) contain the supplementary crystallographic data for this paper.

20 (a) P. Anastas and N. Eghbali, Chem. Soc. Rev., 2010, 39, 301; (b) S. L. Y. Tang, R. L. Smith and M. Poliakoff, Green Chem., 2005, 7, 761; (c) R. A. Sheldon, Chem. Soc. Rev., 2012, 41, 1437; (d) R. A. Sheldon, Chem. Commun., 2008, 3352.

21 R. A. Sheldon, Green Chem., 2007, 9, 1273.

22 (a) R. K. Henderson, C. Jiménez-González, D. J. C. Constable, S. R. Alston, G. G. A. Inglis, G. Fisher, J. Sherwood, S. P. Binks and A. D. Curzons, Green Chem., 2011, 13, 854; (b) P. G. Jessop, Green Chem., 2011, 13, 1391; (c) C. Capello, U. Fischer and K. Hungerbühler, Green Chem., 2007, 9, 927. 23 P. Skehan, R. Storeng, D. Scudiero, A. Monks, J. McMahon, D. Vistica, J. T. Warren, H. Bokesch, S. Kenney and M. R. Boyd, J. Natl. Cancer Inst., 1990, 82, 1107.

24 (a) G. W. Anderson, I. F. Halverstadt, W. H. Miller and R. O. Roblin, J. Am. Chem. Soc., 1945, 67, 2197; (b) W. H. Miller, A. M. Dessert and G. W. Anderson, J. Am. Chem. Soc., 1948, 70, 500. 